\title{
Urban Heat Island Mitigation Strategies: A State-of-the-Art Review on Kuala Lumpur, Singapore and Hong Kong
}

\begin{abstract}
Observing the rapid urban expansions and numerous infrastructure developments in the East-Asian context, many cities are suffering the urban heat island (UHI) effect and its associated environmental and social challenges. Moreover, the lack of sufficient attention to the application of effective heat mitigation strategies in current urban development in these cities can drastically intensify the eventual impacts of UHI. Therefore, many governmental sectors and policy makers have been implementing operative solutions for cooling cities. Nevertheless, this study argues that in Kuala Lumpur, despite the growing attention to this matter, there is still a need for more rigorous consideration by the architecture, engineering and construction (AEC) professionals as well as more scholarly studies to reflect sustainable solutions to the UHI effect. As a result, today, some of the dense urban areas in Kuala Lumpur are characterized with the use of thermally massive building materials, urban surfaces with low albedo, complex urban morphology, waste heat, and low density of vegetation. On the other hand, recent studies demonstrate that there has been a rapidly increasing interest in studies related to UHI in other East Asian regions such as Singapore and Hong Kong. Hence, this study develops a comparative analysis to provide a state-of-the-art review of the recent attempts towards mitigating the UHI effect in Kuala Lumpur, Singapore, and Hong Kong. Among several available UHI mitigation strategies, this study is limited to the analysis of the environmental impacts of urban vegetation (green roofs, green facades, vertical greeneries and green pavements). Findings reveal that in general, urban greening can significantly mitigate the UHI intensity, both directly and indirectly, resulting in the decrease of global air temperature and mean radiant temperature up to $4{ }^{\circ} \mathrm{C}$ and $4.5^{\circ} \mathrm{C}$ respectively. Overall, the study develops new practical guidelines, discusses the public benefits and elaborates on the future directions of UHI studies.
\end{abstract}

Keywords: Urban heat island (UHI), City green areas, High-density urban area, Heat mitigation strategies, Outdoor temperature

\section{Introduction}

Urbanization is described as the process of land use change, whereby population becomes concentrated in towns and cities, representing economic and social modernization (Ren, et al.,2015; Wang, et al., 2015). With regard to the considerable increase of economic growth and social development, substantial labor force tends to migrate from rural to urban-based industrial regions seeking new opportunities for a better life. United Nations Department of Economic and Social Affairs (UNDESA) recently revealed a record indicating a notable increase in the world urban population between the years of 1950, and 2014 (UNDESA/PD,2014). In 1950, 30\% of the world's population was urban, whilst by the end of 2014, this number has been increased to 54\%. As a result of urbanization, the human settlement pattern has undergone significant changes, leading to the intensification of urban economic activities, and production of distinctive negative environmental effects, namely $\mathrm{CO}_{2}$ emission (Al-mulali, Sab, \& Fereidouni,2012; Wang, Chen, \& Kubota2016; Zhang,2016). Additionally, forming 'islands' with higher temperatures in such contexts, central areas of metropolitan cities experience elevated temperatures compared to their rural surroundings (Radhi, Sharples, \& Assem,2015). This difference in temperature is what constitutes the urban heat island (UHI) effect.

In recent years, various studies continuously manifest that the increased ambient air temperature in cities caused by UHI phenomenon embraces enormous negative influences on social, environmental and economic dimensions of cities (Akbari, et al., 2016). As a result, it is of high importance to adequately explore the essence of UHI with viewpoints to its causes and impacts and to study the strategies of UHI mitigation in sustainable ways. More importantly, due to the rapid urban growth and numerous ongoing infrastructure developments in the East-Asian cities, there is an imperative need for more extensive studies on UHI in this context. Many studies reveal that the largest impact of UHI is observed in winter and particularly during the night or early morning periods, nonetheless, the impact of UHI in summer and hot climates has its own specific importance particularly due to its consequential influence on urban thermal discomfort and air quality, air conditioning energy consumption, and heat-related human health issues (Sailor and Dietsch, 2007). Accordingly, this study is 
motivated to look at the current status and future direction of UHI phenomenon and its related scholarly studies in three cities of Kuala Lumpur, Singapore and Hong Kong.

\section{Urban Heat Island (UHI)}

\subsection{The notion of UHI}

UHI is a phenomenon closely associated with the development of cities and urban expansions (Mirzaei, 2015; Morris, et al., 2015). The term 'heat island' generally describes the urbanized areas with higher temperatures compared to their neighboring non-urbanized areas (Arifwidodo \& Chandrasiri, 2015; Fernández, et al., 2015; Kaloustian \& Diab, 2015; Martin, Baudouin, \& Gachon, 2014; Taleb \& Abu-Hijleh, 2013; Tan \& Li, 2015; Zhao, Zhou, \& Liu, 2016). Urban centers typically have higher solar absorption, lower solar reflectivity (albedo) and greater thermal capacity/conductivity compared to the surrounding areas due to their darker and less vegetated surfaces (Kaloustian \& Diab, 2015; Martin, Baudouin, \& Gachon, 2014). Wanphen and Nagano (2009) reported that temperature difference between urban and rural areas can be as high as $5-15{ }^{\circ} \mathrm{C}$. Akbari (2005) similarly characterized UHI as urban areas that are comparatively warmer in regards to solar radiation absorbed by surfaces of buildings and pavements and could not use the natural cooling effect of vegetation in compare with rural areas.

\subsection{Origins of UHI}

The term Urban Heat Island (UHI) appeared for the first time in the English-language meteorological literature in a study by Gordon Manley in 1958 (Landsberg, 1981). However, the first discovery of UHI can be named after Luke Howard in 1820 (Priyadarsini, 2009), when he recognized the existence of a thermal difference between nights and days in London, as nights were $3.7{ }^{\circ} \mathrm{F}$ warmer and days were $0.34{ }^{\circ} \mathrm{F}$ cooler in the city compared to the surroundings (Priyadarsini, 2009). Several causes can be further attributed to the occurrence of UHI in urban contexts as shown in table 1. The foremost reason for thermal difference in nighttime warmth is laid upon the fact that the thermal masses (e.g. buildings) in the urban areas absorb and store the shortwave radiations received throughout the day and release the absorbed energy during the nighttime through longwave radiations (Fernández, et al., 2015). In high-latitude cities with cooler climates, heat islands can be an asset in reducing heating loads, but in mid- and low-latitude cities, heat islands contribute to urban dwellers' summer discomfort and significantly higher air-conditioning loads (Priyadarsini, 2009). Additionally, utilization of materials capable of storing shortwave radiations in the urban landscapes, and lack of evapotranspiration (e.g. shortage of vegetated areas) are also contributed to the appearance of UHI (Chen, et al., 2009; O'Malley, et al., 2015; Schrijvers, et al., 2015; Smith \& Levermore, 2008). Reduction of green spaces in urban landscapes can result in dissipating the shades and cooling effect of trees as well as increasing the $\mathrm{CO}_{2}$ emissions. Materials that are being commonly utilized in constructing pavements and roofs, namely concrete and asphalt have significantly different thermal bulk properties (including heat capacity and thermal conductivity), and surface radiative properties (albedo and emissivity) compared to the ambient rural areas. Consideration of geometric features of urban landscapes is also another important factor influencing the UHI. The existence of tall buildings in big cities can potentially offer multiple surfaces for the reflection and absorption of solar radiations as well as increasing the possibility to proliferate the heat within urban areas (Fernández, et al., 2015). Moreover, location of the buildings in the context of urban landscape can potentially influence the wind circulation throughout the urban inner spaces through blocking the wind, and preventing the cooling process by convection.

Table 1. Occurrence of UHI in urban context by several causes

\begin{tabular}{cc}
\hline Causes & References \\
\hline & (Fernández, et al., 2015; O’Malley, et al., 2015; \\
Anthropogenic heat emissions & Santamouris, Synnefa, \& Karlessi, 2011; \\
& Schrijvers, et al., 2015) \\
\hline Pollution and energy consumption within a city & (Arifwidodo \& Chandrasiri, 2015; Fernández, et \\
& al., 2015; O’Malley, et al., 2015; Santamouris, \\
& Synnefa, \& Karlessi, 2011) \\
\hline
\end{tabular}




\begin{tabular}{cc}
\hline Reduced evaporation & (O’Malley, et al., 2015; Schrijvers, et al., 2015) \\
\hline $\begin{array}{c}\text { Intensive land use and high density in urban areas } \\
\text { combined with buildings with high thermal masses and } \\
\text { heat retaining properties }\end{array}$ & $\begin{array}{c}\text { (Harlan \& Ruddell, 2011; Mavrogianni, et al., } \\
\text { 2011) }\end{array}$ \\
\hline $\begin{array}{c}\text { Urban street canyons effects resulting in lower rates of } \\
\text { long-wave radiation loss during the night }\end{array}$ & $\begin{array}{c}\text { (Santamouris, Synnefa, \& Karlessi, 2011; Smith \& } \\
\text { Levermore, Smith, 2008) }\end{array}$ \\
\hline $\begin{array}{c}\text { Reduced speed of wind caused by design and layout of the } \\
\text { built environment }\end{array}$ & $\begin{array}{c}\text { (Fernández, et al., 2015; Santamouris, Synnefa \& } \\
\text { Karlessi, 2011) }\end{array}$ \\
\hline $\begin{array}{c}\text { Trapping the long wave radiation } \\
\text { (Schrijvers, et al., 2015) }\end{array}$ \\
\hline $\begin{array}{c}\text { reduced permeability } \\
\text { façades and road surfaces }\end{array}$ & (Chen, et al., 2009; Smith \& Levermore, 2008) \\
\hline
\end{tabular}

\subsection{Adverse impacts of UHI}

Negative impacts arising from the development of UHI is generally classified into people and (micro) climates (Dhalluin \& Bozonnet, 2015; O'Malley, et al., 2015). The increase of UHI intensity can negatively affect the citizens' well-being in various ways such as thermoregulatory system damages caused by heat stress appearing in the form of heat syncope, cardiovascular stress, thermal exhaustion, heart stroke and cardiorespiratory diseases (Kleerekoper, van Esch, \& Salcedo, 2012; Rydin, et al., 2012). Strong heat waves, often concomitant with intense UHI, can elevate the demands for air conditioning in buildings, especially among people who are more sensitive to heat (namely elderlies and children) (Dhalluin \& Bozonnet, 2015). Therefore, increased energy consumption as a result of overutilization of mechanical air conditioning systems to cater for accelerated development of UHIs is a major concern. The resultant increase of air temperature can have a detrimental impact on the 'micro-climates' within cities compared to rural areas (O'Malley, et al., 2015; Radhi, Sharples \& Assem, 2015), by formation of ground level ozone (Kleerekoper, van Esch, \& Salcedo, 2012), change of local micro-and macro-climates (i.e. wind patterns, humidity alterations, storms, floods, and change in local ecosystems) (O'Malley, et al., 2015). It is also a key player in worsening global warming conditions (Kolokotroni, et al., 2012).

\section{UHI mitigation strategies}

\subsection{Introducing UHI mitigation strategies in the East Asian countries}

City planners increasingly adopt sustainable solutions (e.g. innovative urban landscape planning and infrastructure design) as active strategies aiming to alleviate the excessive thermal stress associated with UHI. From the central park in New York City to cool roofs in California, from the large city garden in Singapore to patchy urban farms in Europe, one can only be fascinated by the enormous diversity, complexity, and possibility of strategies that cities present in adapting to urban growth and climatic changes. All such strategies constitute common relationships between energy and water cycles, environmental and socio-economic measures, as well as human activities and natural systems. Various universal strategies are commonly applied for UHI mitigation, such as urban morphology design (Tan, Lau, \& Ng, 2016; Wong, et al., 2011), green (vegetated) infrastructure developments (Matthews, Lo, \& Byrne, 2015; Tzoulas, et al., 2007), expansion of highly reflective pavements (Akbari \& Matthews, 2012; Santamouris, 2013) and application of phase-changing materials (PCM) (Abahri, Belarbi \& Trabelsi, 2011; Kuznik, et al., 2011). The basic principle of these strategies generally relies on the modification of surface energy balance over built terrains. For instance, lower albedo pavements reflect more direct solar radiation, whereas urban vegetation tends to redistribute more energy for latent heat of vaporization (Wang, Bou-Zeid, \& Smith, 2013).

The effectiveness of aforementioned UHI mitigation strategies is largely dependent on the environmental conditions including local climatology, geography and surface topology. It is noteworthy that many UHI mitigation strategies are scale-dependent. Their effects at local scale ("tiles" of urban landscape) does not 
necessarily sum up linearly to give net large scale (e.g. city or regional) environmental benefits (Salmond, et al., 2012). It may even lead to unintended consequences (Yang, Wang \& Kaloush, 2015).

\subsection{UHI mitigation criteria}

A series of criteria to evaluate UHI mitigation strategies are discussed. Not all measures should be weighed equally across all mitigation strategies. However, these criteria must be judiciously prioritized under diverse conditions and constraints present in different urban regions (Georgescu, et al., 2015).

\section{$\underline{\text { Environmental temperature }}$}

Environmental temperatures, including air and surface (sometimes subsurface) temperatures are the most important indicators for UHI and surface urban heat island (SUHI). Moreover, the drastic vertical variability in air temperature should be considered in designing and implementing UHI mitigation strategies. Temperature in street canyons has a much steeper vertical gradient near the ground than that at a higher elevation $(>2 \mathrm{~m})$. Though 2-m air temperature is widely used as a measure of UHI intensity, hitherto there is a lack of "standard" air temperature to be used for mitigation strategies across all scales and regions, leading to non-consensus on the measure of UHI mitigation for different strategies, especially among modelers.

\section{Energy consumption/saving}

The reduction of environmental temperature, realized as a result of using UHI mitigation strategies, can effectively decrease the cooling loads of buildings, hence leading to substantial energy saving during hot seasons (Salamanca, et al., 2013; Santamouris, et al., 2001; Wang, et al., 2016). Nevertheless, energy saving benefit needs to be evaluated in conjunction with other environmental impacts of these strategies, examples including human thermal comfort (e.g. additional moisture uptake from urban vegetation), co-benefit of water-energy trade-off and potential heating losses during cold seasons.

\section{Outdoor air quality $(O A Q)$}

The importance of outdoor air quality (OAQ) has been well perceived in the literature in terms of its close association with health concerns (Costa, et al., 2014; Godish, Davis, \& Fu, 2014; World Health Organization (WHO), 2014). As large energy consumers, cities are associated with large power plants and combustion of fossil fuels, which emerge as the main source of air pollutants (Cohen, et al., 2004). UHI tends to degrade the air quality as heat accelerates the chemical reactions in the atmosphere (Walcek \& Yuan, 1995). All UHI mitigation strategies, through reduction of urban environmental temperatures, can directly affect urban OAQ, e.g. lower air temperature can slow the photochemical production of pollutants such as ozone (Taha, 1997).

\subsection{Approaches to studying UHI}

Various approaches including multi-scale phenomena, observational and simulation methods have been designed in previous studies to ascertain the reasons and consequences of UHI presence and also to present solutions to overcome relevant negative impacts (Fernández, et al., 2015; Gluch, Quattrochi \& Luvall, 2006; Huang, et al., 2008; Stewart, 2011; Wang, Berardi \& Akbari, 2016). The trends of techniques established for studying UHI indicates that mathematical models in the simulation methods have progressed substantially during the past two decades due to recent advancements in computational tools (Mirzaei \& Haghighat, 2010). Moreover, multi-scale phenomena and observational approaches have been taken into account in previous studies to review UHI and its effects on outdoor air temperature and OAQ.

\subsubsection{Multi-scale phenomena}

Several phenomena contribute to the formation of UHI in the cities, which are defined as small-scale processes and meso-scale interventions (Mirzaei \& Haghighat, 2010). Consequently, various solutions are necessary to consolidate all these conditions simultaneously. Previous studies have implemented multi-scale approaches to evaluate the overall urban thermal pattern. In a study on urban thermal analysis in Canada, thermal land cover was studied at two scales including the community and regional levels. The study used Airborne ATLAS (Advanced Thermal and Land Applications sensors) to collect the data in the selected scales. Based on the study 
results, the ground-level heat island is marked at both scales where there is a plenty of impervious surfaces (Gluch, Quattrochi \& Luvall, 2006). The stream flow of river was studied in a study by (Adamowski \& Prokoph, 2013 ) to identify how the UHI effect may affect the rivers crossing large urban areas. The study found that there is a direct correlation between annual amplitudes in urban stream flow and annual air temperature amplitudes whereas there was no relation between these factors in the rural situations. Although the multi-scale phenomena were used extensively in these studies, there are serious limitations on use of this technique for studying UHI. The limitation of using this technique is its complexities on providing an inclusive and comprehensive database for a city. In addition, the existing theories in analyzing the corresponding phenomena in each scale are not quite compatible (Mirzaei \& Haghighat, 2010).

\subsubsection{Observational approaches}

Observational approaches including field measurement, thermal remote sensing and small-scale modeling are applicable methods to assess the impacts of UHI in the urban area. Field measurement was established to study UHI since 1818 when Luke Howard used it in London. Subsequently, many studies used this technique in various contexts (Kolokotroni, Giannitsaris \& Watkins, 2006). Near surface temperature in urban area, air velocity, concentration of pollutants and turbulence fluctuations are crucial factors measured in different studies using similar techniques (Arnfield, 2003; Santamouris, 2007).

Field experiment was also carried out to determine the influence of architectural elements on UHI reduction. In a study on the analysis of waterproof membranes for cool roof, full-scale tests were carried out to measure the global solar radiation reflected by each membrane before and after optimization. The in-field experimental tests in the study allowed researchers to specify the optic-energy behavior of the cool membranes (Pisello, et al., 2016). In addition, the meteorological data from the weather stations can be used to identify the UHI effect in a period of time in a city. For instance, in a study in Cyprus, the comparison of the hourly meteorological measurements in the rural and urban area for the period of more than 25 years showed that the UHI effect is stronger during the winter period (Theophilou \& Serghides, 2015).

Although field measurement is widely used in the UHI studies, this technique is also associated with limitations. It is not time-and-cost efficient technique where the comprehensive data should be collected to achieve reliable result. Furthermore, this technique is incapable of identifying all 3D spatial distribution of the quantities in the urban area. This is due to the usage of limited stationary network and relatively low number of measured parameters. Furthermore, it is impossible to generalize the results of a study by making correlation between the data of field study and UHI phenomena due to the effect of other parameters that contribute to the existing UHI intensity.

In the thermal remote sensing approach, satellite or airborne platforms are established to study the UHI. Numerous parameters can be measured through this strategy namely; the resultant surface temperature, surface albedo, turbulent transfer from the surface and surface emissivity (Becker \& Li, 1995). Furthermore, this technique enables comparison of the UHI impact in different cities, using the data collected through the satellites. In a study in the United States, the spatial analysis was implemented to assess the UHI by using land surface temperature data collected by the satellites. The study analyzed the collected data to find the association between the skin temperature amplitude and development intensity and size for 38 cities. The results showed that the urban heat island amplitude is highly related to the city size (Imhoff, et al., 2010).

Thermal remote sensing is not a cost effective approach. Besides, it is impossible to collect the steady images of urban surfaces due to the atmospheric interactions. It is also limited in terms of viewing complete portions of urban surfaces. The vertical field of the study domain cannot be captured in this scheme (Goldreich \& Yair, 2006; Kato \& Yamaguchi, 2005).

As stated by Cermak (1996), small scale modeling defines as replacement of urban area with a prototype for further study. The proposed prototype is evaluated in the wind tunnel or outdoor spaces to explore the UHI effect on parameters like surface temperature in the small scale of a city (de La Flor \& Dominguez, 2004; Uehara, et al., 2000). This technique was rarely used in the previous studies because there are several drawbacks on its application in the UHI studies. It is costly and also it is complicated to create thermal stratification 
experimentally to study the influence of stratification on the pollution concentration. Furthermore, it is a timeconsuming method and only some parts of the area can be investigated (de La Flor \& Domınguez, 2004).

\subsubsection{Simulation approaches}

In addition to observational approaches, computational techniques (based on mathematical problem solving even for large-scale instances) have been constantly progressed through advancement with a rapid pace. Among them, computational fluid dynamics (CFD) and energy balance are the most reliable (Mirzaei \& Haghighat, 2010). The energy balance equation implements the urban canopy model (UCM) for a control volume where the model concerns transition of energy between surface and air temperature in the urban canopy. Unlike the energy balance models, CFD can solve all the fluid governing equations through the urban area simultaneously. Thus, CFD presents more accurate results with regards to UHI distribution within the urban area compared to UCM. However, application of CFD UHI studies is still complicated due to atmospheric interactions of phenomena in a city. As a result, different turbulent models cannot be modeled in the same scale of time and length and it is required to simplify the Navier-Stokes equations in some scales. Thus, two scales are used in UHI studies namely; meso-scale and micro-scale (urban-scale).

Several researchers used the numerical simulation to study UHI around the world (Fernández, et al., 2015; Mirzaei, 2015; Radhi, Sharples \& Assem, 2015; Tsilini, et al., 2015). As a crucial factor, the urban form plays an important role in the mitigation of UHI. However, it is difficult to be evaluated through the previous approaches. CFD simulation enables modelling various urban while still being costly-effective. In a study by Wang, Berardi, \& Akbari (2016), the results of numerical simulation show that duration of direct sun and the mean radiant temperature are affected noticeably by the urban form. Based on the results, the study recommended some design strategies in Toronto, Canada in order to mitigate the UHI for a more sustainable urban planning. As discussed, each of above mentioned approaches has some limitations. Figure 1 presents all approaches to studying UHI along with their limitations.

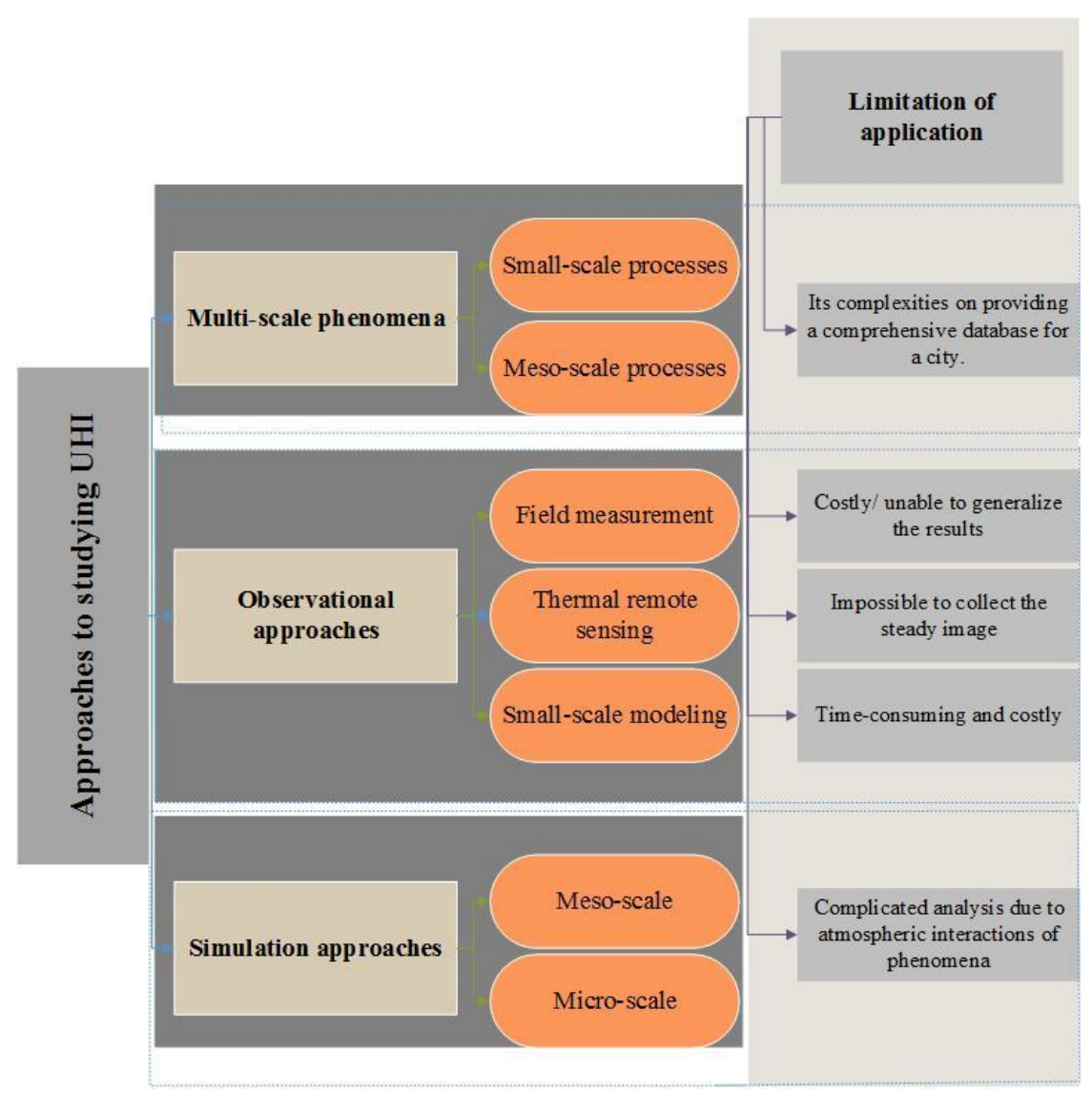

Figure 1. Approaches and methods to studying UHI along with their limitations 


\subsection{Emerging trends to study UHI}

A global surface air warming of between 1.1 and $6.4^{\circ} \mathrm{C}$, an increase in hot extremes and heat wave have been predicted for the $21^{\text {st }}$ century (Change, Intergovernmental Panel On Climate, 2007). In particular, the UHI can influence the alteration of local wind flow pattern, the humidity and the increase of clouds/fog (Srivastava, et al., 2012). Meanwhile, analysis of satellite images discovered that the climates of urban area have a considerable impact on plant growing seasons up to 10 kilometers away from a city's edges (Streutker, 2002).

UHI directly affects the health of urban dwellers. It deteriorates water quality due to transformation of excess heat from hot pavement to storm water draining into sewers while increasing the water temperatures as it is released into rivers/lakes (60). Another significant consequence of UHI is the intensification of energy usage for air-conditioning especially in hot climates. For instance, the UHI imposes residents of Los Angeles to pay approximately US\$ 100 million annually for energy (Taslim, Parapari, \& Shafaghat, 2015).

Due to a number of adverse impacts of UHI, trends to study UHI are highly accelerated in cities throughout the world. Several papers attempted to explore the UHI phenomenon towards offering new solutions for mitigating the UHI intensity (Pisello, et al., 2016; Santamouris, Synnefa, \& Karlessi, 2011), or providing technical reviews (Gago, et al., 2013; Qin, 2015; Santamouris, 2013; Stewart, 2011). Stewart (Stewart, 2011) conducted a comprehensive literature review covering 190 studies from 1950 to 2007 in order to define, measure and present the UHI status and magnitudes reported in the previous studies. The study conclusively proposed five major recommendations aiming to ameliorate the quality of methodologies utilized in UHI studies and provided a critical framework for assessing the current and future UHI status and mitigation approaches. In order to quantify the UHI intensity, fewer field sites in representative locations are preferable to more sites in unrepresentative locations. Furthermore, it is recommended to follow the standardized guidelines for site reporting of UHI magnitudes in urban and rural environments. The study expressed that majority of metadata required for site reporting can be primarily acquired through investigating the field sites, or from meteorological offices, local observers/experts, libraries (e.g. historical photographs, maps), or online portals for digital imagery and mapping (e.g. Google Earth/Maps). Likewise, it showed that guidelines provided by Aguilar et al. (2003 ) and Oke (2004) ideally offered descriptive templates for reporting the micro-, local- and meso-scale settings of temperature measurements in urban and rural environments. Moreover, the study recommended that the honest report of study's limitations in observation is the best practice for sharing and advancing UHI knowledge. It is also recommended that the term of UHI should be utilized for observations which have been sufficiently controlled for non-urban influences. Discretionary use of this term will further promote the control of UHI measurements. Finally, it is suggested that the UHI magnitudes can be only compared with each other, once their extenuating circumstances would be fully disclosed.

In densely urbanized cities such as Kuala Lumpur, Singapore and Hong Kong, several studies have been conducted to determine causes and effects of UHI in urban areas. Furthermore, many strategies are suggested/ implemented in order to mitigate the negative effects of UHI.

\section{Critical review of recent studies on UHI mitigation in Kuala Lumpur, Singapore and Hong Kong}

According to the KOPPEN-Geiger climate classification, Malaysia and Singapore are tropical humid countries. Being close to the equator, the hot and humid conditions are emphasized with heavy rainfall and sunshine throughout the year. The cities have two main seasons including the North-east monsoon (November to March) and the South-west monsoon (June to September). There are two relatively shorter inter-monsoon periods between above-mentioned monsoons. On the other hand, Hong Kong has humid subtropical climate. Springs are the most temperate season due to variable weather conditions; summers are hot and humid with occasional showers and thunderstorms. Autumns feature sunny and dry days, while winters start with moderate and sunny weather until February and then cloudy condition occurs in middle of February.

The area of Kuala Lumpur is 243 square kilometers and its density is 6,891 person per square kilometers (Teriman, Yigitcanlar, \& Mayere, 2009). As shown in Figure 2, the Central Business District (CBD) of city is surrounded by high-rise buildings. Singapore is the second densely populated city in the world. It is an island city-state $648.1 \mathrm{~km}^{2}$ in area. Singapore has 7,987.52 population densities per square kilometer (Seik, 2001). As 
shown in Figure 3, the aerial image shows the dense area at the city center where high amount of heat traps between the buildings or streets. Hong Kong is one of the cities with highest population density in the world particularly due to its limited land. With the land area of $1,100 \mathrm{~km}^{2}$, the population density of city is 6,845 person per square kilometers (Lam, et al., 2005). Figure 4 presents how the skyscrapers built up high density areas in the city center where the lack of open spaces in urban area can be evidently identified.

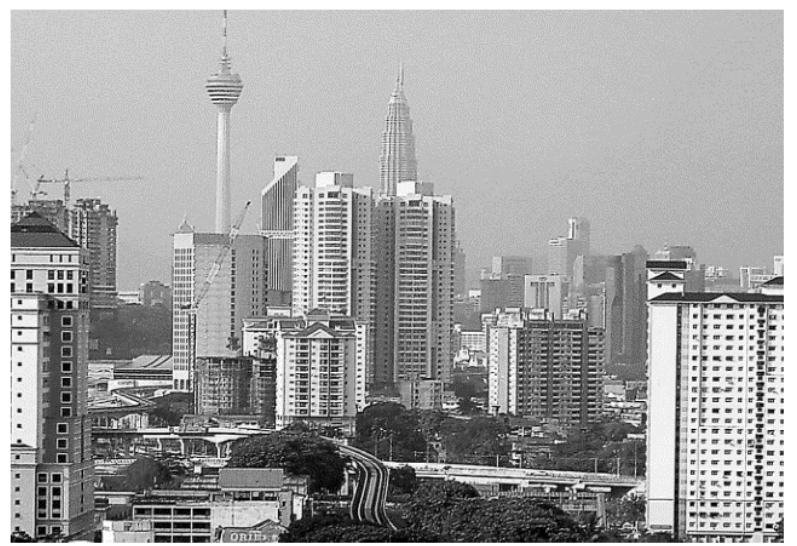

Figure 2. CBD of Kuala Lumpur surrounded by high-rise buildings, Source: (Bunnell, Barter, \& Morshidi, 2002)
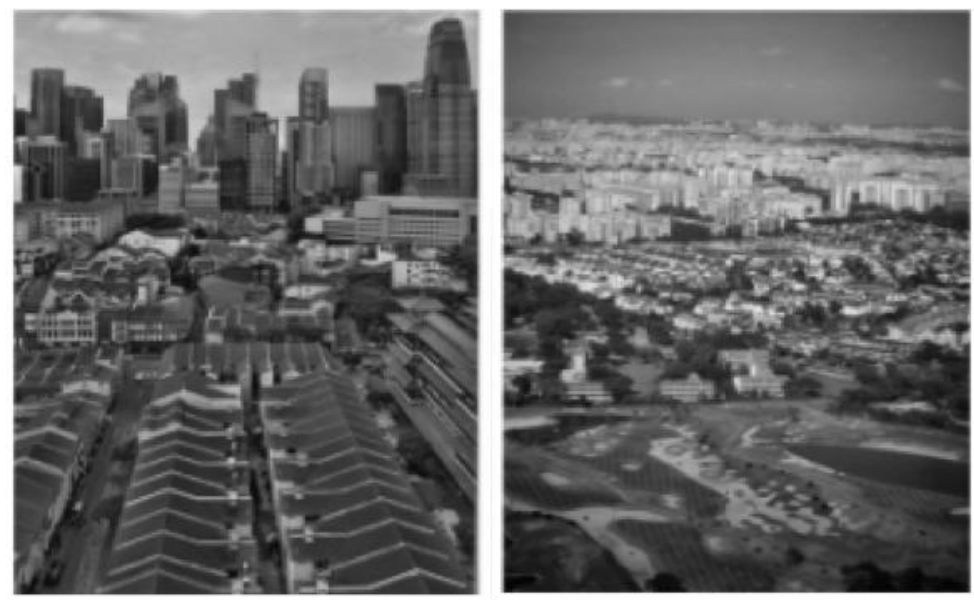

Figure 3. Arial image of skyscrapers in the dense area of Singapore city, Source: (Belle, Wang, \& Hassler, 2015)

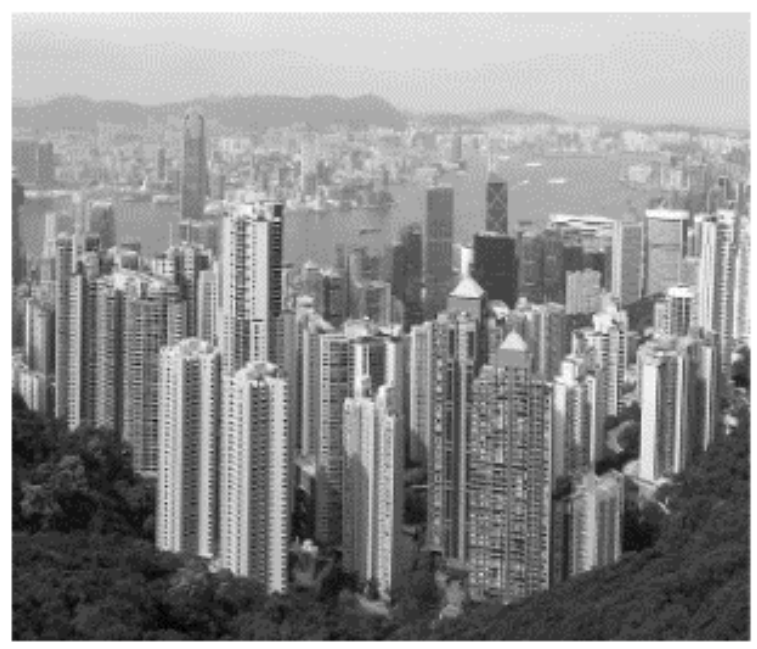

Figure 4. High-rise high density urban area of Hong Kong, Source: (Pan, Qin, \& Zhao, 2016) 
As shown in Figure 5, the street level examples observed in Singapore, Hong Kong, and Kuala Lumpur are presented, with a vivid representation of the sky view factors inside street canyons of these cities.

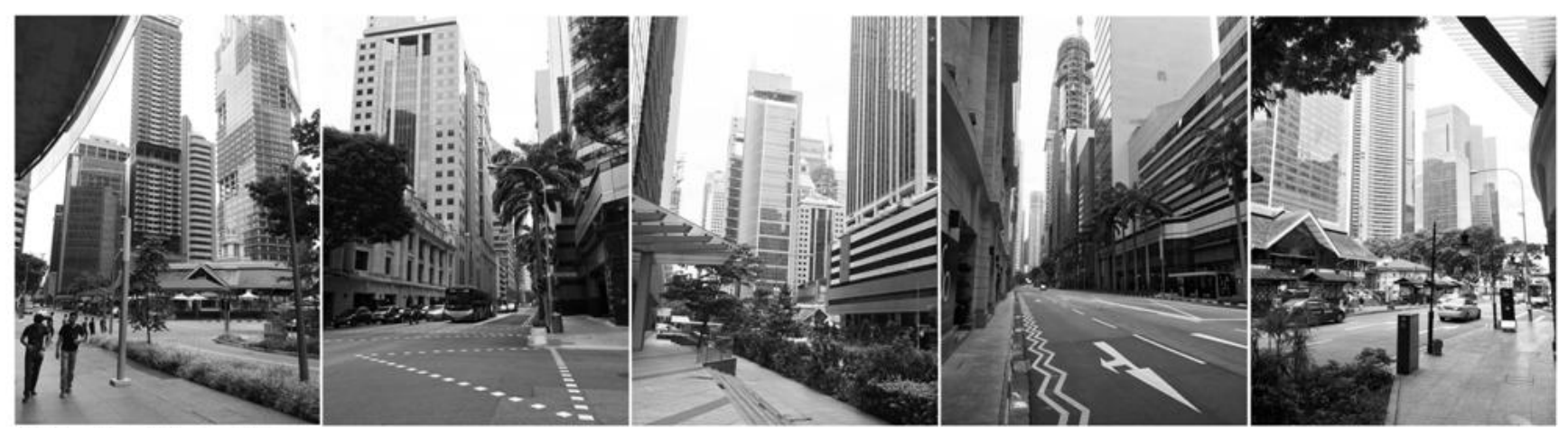

A) Street level photos of Singapore

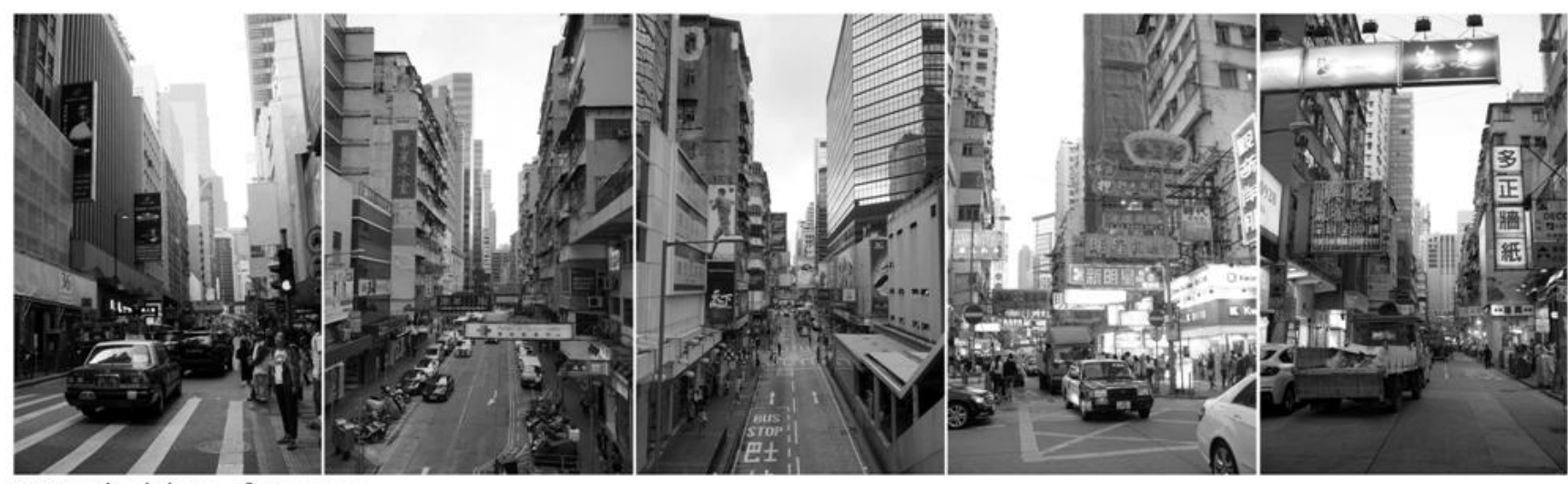

B) Street level photos of Hong Kong
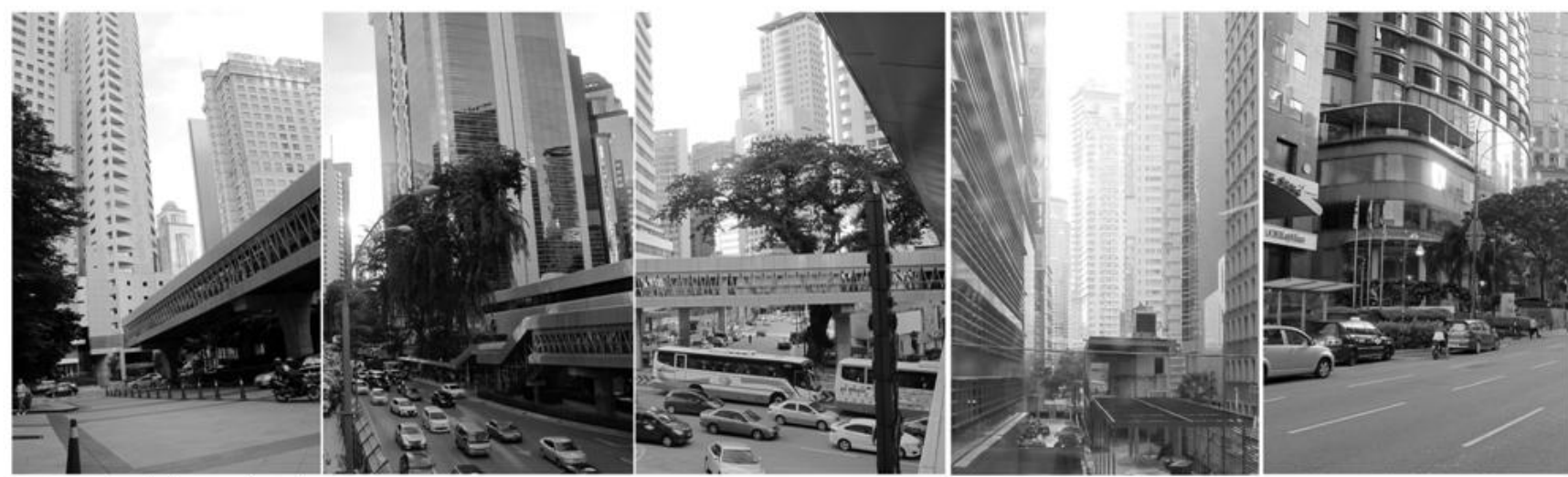

C) Street level photos of Kuala Lumpur

Figure 5. Street level photos of A) Singapore B) Hong Kong C) Kuala Lumpur. Source for 5A and 5b: Edward $\mathrm{Ng}-$ Source for 5C: Authors

\subsection{Overview of the selected cities}

\subsubsection{Kuala Lumpur}

\section{a) Introduction}

Malaysia is positioned on the South China Sea and lies between $1^{\circ}$ and $7^{\circ}$ in North latitude and $100^{\circ}$ and $120^{\circ}$ in East longitude (Mekhilef, et al., 2012). Kuala Lumpur is the federal capital of Malaysia locating on latitude $3^{\circ} 9$ $\mathrm{N}$ and longitude $101^{\circ} \mathrm{E}$ with the elevation of $56 \mathrm{~m}$ above sea level (Tso, 1996). This city hosts a population of 
1.67 million (2010 census) (Bunnell, Barter, \& Morshidi, 2002). Kuala Lumpur possesses a tropical rainforest climate which is warm and sunny, along with abundant rainfall. The maximum temperature of this city ranges between $32^{\circ} \mathrm{C}$ and $33^{\circ} \mathrm{C}$, while the minimum temperature is between $23.4^{\circ}$ and $24.6^{\circ} \mathrm{C}$.

\section{b) Climate and Related Environmental Issues}

Kuala Lumpur which is originally located in a densely forested tropical region, has been experiencing a considerable rate of urbanization during the last decades. This trend of urban expansion is associated with emerging environmental issues such as reduction of forest cover, increasing the health concerns, polluting the rivers and affecting the fishery industry, as well as air pollution, and UHI effects (Morris, et al., 2015; Poon, 2016; Sahrir, Bachok, \& Osman, 2014; Webb, 1998). Correspondingly, various schemes have been launched in order to regulate the negative effects of urbanization and direct Kuala Lumpur toward the so-called green and livable city by 2020, namely Kuala Lumpur Structure Plan 2020 (Kuala Lumpur Structure Plan, 2016), or Greener Kuala Lumpur project which aims to increase greenery in the city by planting 100,000 large-coverage trees by the year 2020 (EPP 6, 2016). Kuala Lumpur is currently possessed $11 \mathrm{~m}^{2}$ of green space per person, which is lower in comparison with $22 \mathrm{~m}^{2}$ in the top livable cities in the world.

\section{c) Urban Characteristics and Land Use Patterns}

Kuala Lumpur has garnered considerable advancements during the last decades in terms of urban developments and emerging the signs of urbanization. Numerous ongoing construction and infrastructural developments observed in this city clearly present its rapid urbanization growth. However, there are still several deficiencies identified in the current situation of Kuala Lumpur by Kuala Lumpur Structure Plan 2020 and aimed to be improved by this year (Kuala Lumpur Structure Plan, 2016). These urban-related issues are categorized in four major groups, including i) Urban form, ii) Urban linkages, iii) Urban identity, and iv) Urban design policies. The ultimate objective of this plan visions Malaysia as a fully developed country economically, socially, politically and spiritually by the year 2020 .

\subsubsection{Singapore}

\section{a) Introduction}

Singapore is an Island state located $\left(1^{\circ} \mathrm{N}, 104^{\circ} \mathrm{E}\right)$ at the southern tip of Peninsular Malaysia covering an area of $712 \mathrm{~km}^{2}$ and a population of 5.4 million (2013 census) (Roth \& Chow, 2012). This Island has a wet climate with consistently high monthly mean temperatures and minor monthly variation (annual mean of $\sim 27.5^{\circ} \mathrm{C}$; monthly range $\left.<2{ }^{\circ} \mathrm{C}\right)$. Singapore possesses a relatively small diurnal temperature range $\left(\sim 7^{\circ} \mathrm{C}\right)$ and high annual total precipitation (mean rainfall $\sim 2190 \mathrm{~mm}$ ) (Roth \& Chow, 2012). This country is also subjected to regional climate variations caused by the Asian monsoon, with weak mean surface winds (monthly mean $<3 \mathrm{~m} \mathrm{~s}^{-1}$ ) predominantly from the northeast during the Northern Hemisphere winter months (December-March), and a regular seasonal reversal to the southwest during the summer months (Population and Population Structure, 2016).

\section{b) Climate and Related Environmental Issues}

The rapid rate of urban growth in Singapore makes this city an extreme case of urbanization within Southeast Asia countries (Tan \& bin Abdul Hamid, 2014). The high pace of urbanization is causing diminishing forest density in Singapore, by which it currently has the lowest amount of its original forest area left intact compared to its Southeast Asian neighbors (Corlett, 2011). Of the original lowland tropical rainforest that almost entirely covered the island before the founding of modern Singapore in 1819, only 200 hectares, or $0.28 \%$ of its current total land area of $712 \mathrm{~km}^{2}$ is remained (Tan \& bin Abdul Hamid, 2014). The rate of urbanization in Singapore is high even when compared to the exponential increase in urban areas of Phoenix and Las Vegas, two of the fastest growing metropolitan regions in the United States (Wu, 2011). Consequently, future urbanization can potentially trigger increasing the UHI effects in Singapore and endangering this city with further environmental issues. 


\section{c) Urban Characteristics and Land Use Patterns}

Singapore is known as a garden city without a distinct borderline between urban and rural areas. However, this city has two existing predominant green areas, including a primary forest of 75 ha in the middle of the island and the open space/recreation area in the northeast of the island, which are basically located at the northern part of the country (Wong \& Yu, 2005). Majority of built-up (developed) regions such as commercial and residential areas, are located at the southern part (Wong \& Yu, 2005). The necessity to respond to the housing demands caused this city to alter the land use pattern from green areas into newly built structures. This alteration in mindset of urban design coupled with the rapid pace of urbanization making Singapore currently known as one of the most urbanized state in Southeast Asia, and an example of high-density and compact city in the world (Tan \& bin Abdul Hamid, 2014).

\subsubsection{Hong Kong}

\section{a) Introduction}

Hong Kong is situated at the south coast of China, at $22^{\circ} \mathrm{N}$ latitude and $114^{\circ} \mathrm{E}$ longitude with a typical humidsubtropical climate (Peng \& Jim, 2015). This city usually has long and hot summers lasting from late April to September with average daily maximum air temperature exceeding $33^{\circ} \mathrm{C}$ (Peng \& Jim, 2015). Hong Kong is a special administrative region of China, which is a world-class financial, trading and business center of about 7.2 million people with an area of 1,104 $\mathrm{km}^{2}$ (Ma, 2014). Regarding to the population and occupied area of this city, Hong Kong is characterized as one of the most densely populated cities in the world. The extremely hot summers in conjunction with dense population and exceptionally compact urban morphology have resulted in strong UHI effects and extensive use of energy for cooling. This further leads to large amount of upstream emissions of GHGs and other air pollutants such as $\mathrm{SO}_{2}$ due to fuel combustion at local power stations. The densely packed high-rise buildings often obstruct natural ventilation and air circulation, inducing trap of air pollutants in the urban canopy layer. The urban natural system shows limited capacity in environmental restoration due to lack of ground-level green spaces (Peng \& Jim, 2015).

\section{b) Climate and Related Environmental Issues}

The rapid urbanization and continuous land demands for housing and infrastructures resulted in posing serious threats on local environment. The Hong Kong Observatory analyzed the data of annual mean temperature from 1885 to 2015 , and reported an average rise of $0.12^{\circ} \mathrm{C}$ per decade (The government of the Hong Kong Special Administrative Region, 2016). This increase in temperature can further associate with increasing the energy consumption in buildings and GHG emissions in urban areas (Peng \& Jim, 2015). Furthermore, the high population density and rapid urban growth is instigated the increase of Hong Kong's vulnerability towards the climate change. As one of the world's high-density cities, Hong Kong is repeatedly identified in the literature as a city suffering from severe UHI effects (Siu \& Hart 2013; Tan, Lau \& Ng, 2016).

\section{c) Urban Characteristics and Land Use Patterns}

Physically, the urban development of land use pattern is dependent on terrain conditions, population, legal restrictions, cultures, etc. (Wang, Zhang \& Skitmore, 2015). In Hong Kong, land use policies are developed in accordance with the local characteristics of this country, which are mainly comprised of rugged and hilly topography (Deng, Chan \& Poon, 2016; Zhang \& Jim, 2014). Currently, the built-up areas occupy approximately $22 \%$ to $25 \%$ of the territory $\left(1,104 \mathrm{~km}^{2}\right.$ ) (Wang, Zhang, \& Skitmore, 2015; Zhang \& Jim, 2014). In this context, there is an extreme scarcity of land for urban growth and urgent need for seeking sustainable land use for Hong Kong. Correspondingly, government launched various schemes aiming to respond the increasing housing demands, namely initiating the Public Housing in Hong Kong (Deng, Chan, \& Poon, 2016), or developing several programs which are based upon the reutilization of land resources such as Rezoning Land, Land Resumption, Rock Cavern Development, Redevelopment, Reclamation and Reuse of Ex-quarry Sites (Wang, et al., 2013). Notwithstanding these efforts, Hong Kong is considered as one of the intensely urbanized areas in the world that suffers from the strongest UHI problems (Wong \& Lau, 2013). The lack of vegetation and public open space in the urban environment in Hong Kong facilitates the absorption of solar heat in the daytime, which enhances the formation of the UHI (Wong \& Lau, 2013). Furthermore, many of newly-developed buildings in 
the urban centers or redevelopment zones in Hong Kong have been arranged in a 'wall-type' fashion, which are subsequently resulted in obstructing the natural ventilation, wind circulation, and blocking the flow of fresh air into the city, hence forming a 'canyon' effect where pollutants are trapped at the street level between buildings. Moreover, the extreme hot summers have become prevalent in Hong Kong over the last decades. As a result, high urban temperature and pollutant levels and poor natural air circulation have then led to an extensive use of air-conditioning systems to cool down the temperature in the urban environment. This leads to further heating and carbon dioxide release (Wong \& Lau, 2013), which causes negative impacts on the urban sustainability and increases the possibility of people getting respiratory diseases.

\subsection{Urban morphology and building forms}

\section{Hong Kong}

Suffering from severe negative UHI effects, the annual UHI intensity in Hong Kong ranges between $2^{\circ} \mathrm{C}$ to $4^{\circ} \mathrm{C}$ (Siu \& Hart, 2013). Several researchers endeavored to address this issue (Chan, 2011; Nichol, et al., 2009; Paulina, Poh-Chin, \& Melissa, 2015; Shi,et al., 2015; Siu \& Hart, 2013; Tan, Lau, \& Ng, 2016; Wong, et al., 2016; Wong, et al., (2016)). Nichol, et al. (Nichol, et al., 2009) used thermal satellite images combined with 'in situ' ground data in order to examine models of heat island genesis and thus identify the main causes of UHI in Hong Kong. The acquired image and ground data suggested that the urban canopy layer climate was mainly influenced by local city structure. Tan, Z., et al. (Tan, Lau, \& Ng, 2016) examined two morphology-based planning approaches, the sky view factor (SVF)-based design and the wind-path design approach aiming to enhance the thermal benefits and mitigate the daytime UHI effects. The results demonstrated that, tree planting in conjunction with proper planning is an effective measure to mitigate daytime UHI in Hong Kong. Chan (2011) also developed a 'typical meteorological year' weather file (TMY) using the site measurements and morphing procedures aiming to accurately assess the UHI effects during the summer season. The research identified that, there was an approximately $10 \%$ increase in the cooling demands during summer times for buildings located in the urban area in comparison with the buildings in rural areas. The results also showed that, there was a potential to mitigate the building energy consumption as well as GHG emissions by a maximum of $10 \%$ through using various UHI mitigation measures.

In another study, Paulina, Poh-Chin, \& Melissa (2015) proposed a low-cost methodology through deploying small and inexpensive sensors aiming to carry out continuous measurements of microclimate data at two representative urban communities in Hong Kong. The network of sensors applied to record the road-side temperature and relative humidity at 15 -minute intervals for 2 weeks in the summer and repeat this procedure in the winter. Meteorological and environmental factors influencing UHI were also statistically analyzed by automatic linear regression models. Regression results indicated that, the solar radiation and greenery density were the most important factors with a negative association with UHI intensities in both seasons. Shi, Y., et al. (2015) investigated the spatial distribution of microclimatic condition in Hong Kong. They measured air temperature, wind speed, relative humidity and globe temperature of 87 locations in two selected sites in a summer day as well as a winter day. Both numerical simulation and geographical mapping approach were utilized aiming to estimate the micrometeorological spatial distribution. The results showed that, the impact of urban morphology on the microclimatic spatial distribution can be well investigated by employing numerical simulation. Moreover, the geographical mapping indicating the higher estimation accuracy by accounting anthropogenic heat and other factors associated with human activities. Likewise, Wong, P. P. Y., et al (2016) selected Mong Kok and Causeway Bay, two typical urban communities in Hong Kong, to gather evidences of microclimate variation and sources of thermal discomfort. In order to estimate UHI, 58 logging sensors placed at strategic locations were used to record temperature and humidity measurements over 17 consecutive days each in the summer/hot and winter/cool periods. These measurements were geocoded and plotted over the built landscape through employing geographic information and global positioning systems aiming to convey microclimate variation. The empirical data were further aligned with distinct environmental settings to associate possible factors contributing to UHIs. This study established the existence and extent of microclimate variation of UHI within urban communities of different environmental configuration and functional uses. 


\section{Kuala Lumpur}

The first study conducted to investigate the availability of UHI in Kuala Lumpur was performed by Sham in 1973 (Elsayed, 2012), when he realized that, the temperatures were higher in central districts compared to the rural areas. Afterwards, the status of UHI intensity has been investigated by other sources of literature. In one of the recent studies, Ahmed, et al. (Ahmed, et al., 2015) studied the behavior of surface temperature and the effects of heat island in Putrajaya, Kuala Lumpur. The results indicate the existence of an average heat island intensity of $2^{\circ} \mathrm{C}$ at nighttime while this value during the daytime was negligible. Morris, K.I., et al. (Morris, et al., 2015) carried out a study to investigate the existence and distribution of UHI, as well as thermal behavior of urban canopy layer in Putrajaya, Kuala Lumpur. They developed a numerical mesoscale Weather Research and Forecasting (WRF) Model coupled with Noah land surface model and a single layer urban canopy model (UCM). The model was able to capture the diurnal behavior of the validated data, and successfully simulate some of the features of UHI effects such as day and night variations. The results obtained from the model were further verified with in situ studies of the area, and observational data acquired from Alam Sekitar Malaysia Sdn Bhd (ASMA). The outcomes of this study indicated that, UHI intensity of Putrajaya varied temporally and spatially by increasing during the night to a peak value $3.1^{\circ} \mathrm{C}$, and then decreasing in the morning. It was also stated that, the magnitude of UHI can be influenced by the ratio of green land coverage. In another attempt, Morris, K. I., et al. (Morris, et al., 2016) investigated the chronological local urban climate alterations occurred over a decade (1999-2011) of urbanization through utilizing the NCAR WRF model coupled with a numerically proven land surface and urban canopy model (NOAH LSM/UCM). LANDSAT images were also used to acquire up-to-date and precise land cover dataset of the region implemented for each year. Model results were further evaluated against a network of observational studies in the region. They also examined the air temperature, wind speed, relative humidity, planetary boundary layer height and urban warming of the area in each of the considered years. It was concluded that, the temperature of area was increased at the rate of $1.66{ }^{\circ} \mathrm{C}$ per decade, while the prevailing UHI intensity of the area was approximately $2.1^{\circ} \mathrm{C}$.

In another study, Yusuf, Pradhan, \& Idrees (2014) examined the effectiveness of quantifying the UHI impacts through utilizing the remote sensing data as well as finding the relationship between UHI and land use change. They used Landsat TM/ETM imagery acquired between 1997 and 2013 in order to extract the ground brightness temperature and land use/land cover change in Kuala Lumpur metropolis. They claimed that UHI truly exists in the Kuala Lumpur city, considering the fact that the average temperature was sharply increased from $38.8{ }^{\circ} \mathrm{C}$ to $47.8{ }^{\circ} \mathrm{C}$ during the period of investigation. It was also pointed out that, the urban morphology can have a direct impact on the heat generated within the city context. Rajagopalan, Lim, \& Jamei (2014) investigated the actuality of UHI and its possible causes in Muar, which is known as one of the fast growing cities in southern part of Malaysia, and then examined the effects of different urban geometry on the wind flow. The results of this study indicated that the fast-paced development of this city has resulted in the reduction of ventilation in urban canyons. The intensity of UHI in the city center was recorded as $4{ }^{\circ} \mathrm{C}$ during the day and $3.2{ }^{\circ} \mathrm{C}$ during the night. Investigation of various urban geometry modifications showed that step-up configuration was the most effective geometry due to its significant influence on distributing the wind evenly and allowing the wind to reach even the leeward side of each building.

\section{Singapore}

Jusuf, S.K., et al. (2007) investigated the effects of land use types on increasing the ambient temperature in Singapore. They utilized remote sensing data and geographical information system (GIS) in order to obtain a macro view of Singapore and carry out a comprehensive analysis simultaneously. The results revealed that, urban land use pattern can significantly influence the urban temperature. Hence, it was concluded that, by means of proper application of land use planning, UHI can be mitigated. Priyadarsini \& Wong (2007) also carried out a research to explore the existence and severity of UHI effects in Singapore through conducting extensive field measurements. The results divulged that in high-rise commercial areas with high density, the air temperature increased by $2^{\circ} \mathrm{C}$ during the night. During the day, the dense urban fabric provided solar shading within the deep street canyons and the shaded area between tall buildings showed lower temperatures compared to areas with low-rise buildings. In another attempt, Priyadarsini, Hien, \& David (2008) investigated the UHI effects in Singapore and examined the key factors causing these effects. They used CFD simulation to explore the effects 
of building geometry, facade materials and the location of air-conditioning condensers on the outdoor air temperature. It was found that, at very low wind speeds, the effect of facade materials and their colors was very significant. They also found that, limited use of high-rise buildings can enhance the air flow inside the canyon, thereby reducing the air temperature. Boehme, Berger, \& Massier (2015) proposed a methodology capable of producing sufficient UHI models through identifying areas with significant anthropogenic heat emissions. This methodology is based on combining a top-down disaggregation of sectorial electricity consumption with a bottom-up GIS derived building database for obtaining anthropogenic heat emission maps with high spatial resolution. They claimed that the proposed methodology can be used for cities where the energy demand data is insufficient. On the other hand, Chow \& Roth (2006) examined the temporal variability of the canopy-level UHI of Singapore for different temporal scales on the basis of observations during a 1-year period. Temperature data acquired from different urban areas including commercial, Central Business District (CBD), high-rise and lowrise housing were compared with rural reference data, and analyzed with respect to meteorological variables and differences in land use. It was found that, the higher UHI intensities generally occurred during the southwest monsoon period of May-August, with a maximum of $\sim 7{ }^{\circ} \mathrm{C}$ observed in the commercial area under ideal meteorological conditions.

In conclusion, the importance of UHI has been well-perceived by the reviewed studies that were carried out in this field with the purpose of determining the magnitude of UHI effects. The findings of reviewed studies indicate the existence of UHI in all the three cities. In general, it is suggested that, proper land use planning, increasing the use of urban vegetation, and UHI-aware design of high-rise buildings can be suitable solutions to mitigate the UHI effects in the urban areas.

\subsection{Low albedo and building material}

Materials used in building facades in urban areas influence the urban thermal balance significantly. The solar radiation absorbed by the building materials is dissipated by convective and radiative heat transfer into the urban atmosphere and increases air temperature consequently. Therefore, appropriate selection of materials can provide the opportunities to reduce the energy consumption as well as improving the comfort conditions of individual buildings and urban spaces (Santamouris, Synnefa, \& Karlessi, 2011).

Urban greenery can be used as a low albedo finishing material on building rooftops. A study in Singapore ascertained that mean radiant temperature above the rooftop garden is significantly lower than that of a concrete roof. The study also provided a prediction model for the selection of plants as low albedo materials for cooling potential enhancement (Tan, et al., 2015).

\section{Hong Kong}

A study in Hong Kong showed that nighttime ventilation should be applied by substantial variation in the ground surface of the case study to enhance ventilation level. It can be ensured that pleasant outdoor condition may be achieved through the proper selection of materials with various albedo levels (Giridharan, Lau, \& Ganesan, 2005). In a study in Hong Kong, an analysis has been carried out to evaluate surface albedo in a high-density residential area. The results showed that the outdoor air temperature at a lower sky view factor between 0.1 to 0.25 and shrub cover below than $15 \%$ in $1000 \mathrm{~m}^{2}$ open area is less than that in the same level of tree cover with a higher sky view factor (0.4 or above) (Giridharan, et al., 2008).

\section{Kuala Lumpur}

In a study in Kuala Lumpur, cool materials (albedo of 0.8) integrated with higher levels of tree canopy density $(\mathrm{LAI}=9.7)$ were compared with the current environmental conditions to identify how the integrated design could reduce the outdoor air temperature. The results showed that the average outdoor air temperature was reduced up to $2.7^{\circ} \mathrm{C}$ through the application of the proposed design (Shahidan, et al., 2012). In another study, it was found that replacing natural green areas with vegetated areas specified as more cooling material can reduce ambient air temperature in urban area significantly (Buyadi, Mohd, \& Misni, 2015). 


\subsection{Green roof, green façade, vertical greenery and pavement}

\subsubsection{Green roof studies}

Application of green roofs, green façades and vertical greenery systems on the surface of a building can potentially mitigate the UHI phenomenon (Alexandri \& Jones, 2008). Several researchers were carried out to investigate the relationship between utilization of green envelope and mitigation of local temperature (Oberndorfer, et al., 2007; Sailor, et al., 2008; Takebayashi \& Moriyama, 2007). In the urban contexts, roofs commonly engross up to $25 \%$ of the areas in cities (Akbari, Rose, \& Taha, 2003). In particular, green roofs have various advantages in view to the mitigation of negative UHI effects (Takebayashi \& Moriyama, 2007). The results of studies conducted on the effects of green roofs, green façade and greenery on UHI mitigation are tabulated in Table 2.

Table 2. Impact of green roofs, green façades and greenery on UHI mitigation

\begin{tabular}{|c|c|c|c|c|}
\hline Author & Method & Parameter & Results & Location \\
\hline $\begin{array}{l}\text { (Wong, et al., } \\
\text { 2003) }\end{array}$ & $\begin{array}{c}\text { Field } \\
\text { measurement }\end{array}$ & Temperature & $\begin{array}{l}\text { Mitigating the global temperature by } 4.05^{\circ} \mathrm{C} \\
\text { and mean radiant temperature by } 4.5^{\circ} \mathrm{C} \\
\text { consequently reducing the } \mathrm{UHI} \text { impact }\end{array}$ & Singapore \\
\hline (Jim, 2015) & $\begin{array}{c}\text { Field } \\
\text { measurement }\end{array}$ & $\begin{array}{l}\text { Temperature } \\
\text { Energy } \\
\text { consumption }\end{array}$ & $\begin{array}{c}\text { Reducing the environment temperature since } \\
\text { high rate of evapotranspiration of vegetated } \\
\text { surface decrease the UHI effect }\end{array}$ & Hong Kong \\
\hline $\begin{array}{c}\text { (Ismail, Samad, \& } \\
\text { Rahman, 2011) }\end{array}$ & $\begin{array}{c}\text { Field } \\
\text { measurement }\end{array}$ & Temperature & $\begin{array}{l}\text { Indoor surface temperature of a green roof } \\
\text { building was } 6.855^{\circ} \mathrm{C} \text { lower compared to black } \\
\text { bare roof. } \\
\text { Less } \mathrm{CO}_{2} \text { emission and heat gain occurred due } \\
\text { to green roof implantation reducing the UHI }\end{array}$ & Malaysia \\
\hline $\begin{array}{l}\text { (Wong, et al., } \\
\text { 2009) }\end{array}$ & Simulation & $\begin{array}{l}\text { Temperature } \\
\text { Energy } \\
\text { consumption }\end{array}$ & $\begin{array}{l}\text { Vertical greenery systems could reduce the } \\
\text { UHI by } 100 \% \text { greenery coverage which } \\
\text { mitigate the estate air temperature by } 1^{\circ} \mathrm{C}\end{array}$ & Singapore \\
\hline $\begin{array}{l}\text { (Cheng, Cheung, } \\
\text { \& Chu, 2010) }\end{array}$ & $\begin{array}{c}\text { Field } \\
\text { measurement }\end{array}$ & $\begin{array}{l}\text { Temperature } \\
\text { Energy } \\
\text { consumption }\end{array}$ & $\begin{array}{l}\text { The employment of vertical greenery system } \\
\text { disabled solar heat to be penetrated into the } \\
\text { building. Furthermore, replacement of bare } \\
\text { concrete used in the building envelope with } \\
\text { green wall resulted in reducing the energy } \\
\text { consumption by 30\%. }\end{array}$ & Hong Kong \\
\hline $\begin{array}{l}\text { (Wong, et al., } \\
\text { 2010) }\end{array}$ & $\begin{array}{c}\text { Field } \\
\text { measurement }\end{array}$ & Temperature & $\begin{array}{l}\text { Energy saving and cooler ambient temperature } \\
\text { happened due to vertical greenery systems. } \\
\text { Wall and substrate temperature of vertical } \\
\text { green system are } 4-12^{\circ} \mathrm{C} \text { and } 9{ }^{\circ} \mathrm{C} \text { lower than } \\
\text { that of control wall respectively }\end{array}$ & Singapore \\
\hline $\begin{array}{l}\text { (Wong, et al., } \\
\text { 2007) }\end{array}$ & $\begin{array}{l}\text { Satellite image } \\
\text { Simulation } \\
\text { Field } \\
\text { measurement }\end{array}$ & Temperature & $\begin{array}{c}\text { Ambient temperature reduces on building near } \\
\text { or surrounded by green space and it will make } \\
\text { environment cooler in general. }\end{array}$ & Singapore \\
\hline $\begin{array}{l}\text { (Wong \& Yu, } \\
\text { 2005) }\end{array}$ & Mobile survey & Temperature & $\begin{array}{l}\text { The difference of } 4.01^{\circ} \mathrm{C} \text { was explored in } \\
\text { compare between vegetation area and the } \\
\text { central business district area and this study } \\
\text { indicated the temperature mitigation of planted } \\
\text { area at macro level. }\end{array}$ & Singapore \\
\hline
\end{tabular}

Wong, N.H., et al. (2003) demonstrated that; building roofs in Singapore are accountable for a considerable portion of solar heat gained by the building envelope. They also ascertained that vegetated roofs can effectively mitigate the UHI impacts in urban environment. In another study, Jim (2015) developed a full-scale experiment 
aiming to evaluate the effects of green roof installed in a Hong Kong high-rise residential building on thermal energy performance with regards to the adaptive thermal comfort in hot and humid climates. Precision sensors were also installed along with a holistic vertical temperature profile extending from outdoor environment to roof surface, green-roof material layers, indoor ceiling and indoor environment. It was concluded that the application of vegetated roof with high rate of evapotranspiration can cool down the foliage surface and surrounding air to modify and mitigate UHI impacts. A railway station in humid-subtropical based study by C.Y. Jim showed more roof greening benefits including mitigation in cooling load and energy consumption (Jim \& Peng, 2012). That is to say, with a green roof, a significant reduction in the electricity consumption for air-conditioning could also occur due to soil water availability that regulates the evaporative cooling by roof vegetation (Tsang \& Jim, 2011).

On the other side, Li \& Norford (2016) investigated the effects of employing cool roof and green vegetation on the mitigation of UHI in Singapore. The results revealed that the deployment of cool roofs in the city-scale facilitated the reduction of the near-surface air temperature and surface skin temperature during the daytime (especially at noon), but has little effect during nighttime. Moreover, it was found that the utilization of green vegetation in the city-scale can diminish the near-surface air temperature by more than $1{ }^{\circ} \mathrm{C}$ during nighttime when the UHI intensity is high. The findings also presented the positive impacts of using green vegetation on the improvement of human's physiological thermal comfort during early morning. These findings were also confirmed by a similar study carried out by Chow, W. T., et al (2016), whereby they investigated microclimatic differences within an urban park in Singapore in order to assess the effects of variations in plot-scale land cover on the microclimate data. The results demonstrated that the characteristics of vegetation canopy can significantly affect the wind and sun exposure which are known as the two important factors in outdoor thermal comfort. In another attempt, Wong et al. explored that the saving energy on the five-story commercial building could be between 0.6 to $14.5 \%$ in annual energy consumption. Simulation results showed that building energy consumption reduction depends on soil thickness and the moisture content of soil (Wong, et al., 2003).

Green roof offers both active and passive cooling (active by evaporative cooling and passive by insulation), to indoor spaces especially in tropical climate where the improvement of building thermal performance and decrease of energy consumption are critical. Ismail, A., et al. (2011) carried out an experimental study to investigate the direct effects of roofs on the indoor air temperature in Malaysia. For this purpose, different types of roofs including black bare roof, white roof and green roof were installed in a single story house. Several sensors were used in order to measure the thermal behaviours of these roofs. Results revealed that the indoor air temperature was significantly reduced under white and green roofs in comparison to the black bare roof. In addition, comparison of results between the black and green roof showed that the indoor surface temperature on the green roof was about $6.85^{\circ} \mathrm{C}$ less than the black bare roof in the afternoon. Findings also indicated the potential of green roofs in mitigating the UHI effects through diminishing $\mathrm{CO}_{2}$ emission and excess heat.

\subsubsection{Studies on vertical greenery}

Vertical greenery is a crucial element in reducing UHI impacts especially in metropolitan cities. A study in Singapore, evaluated the effects of plants on the building envelope in order to reduce the estate air temperature and energy consumption (Wong, et al., 2009). The study used numerical simulation to demonstrate and compare vertical greenery techniques with glass surface in the building envelope on the reduction of Mean Radiant Temperature (MRT). Based on a simulation model heat transfer was mitigated by plants covering the envelope. An air temperature prediction model used to evaluate existing micro-climatic condition. The results showed that vertical greenery techniques can mitigate the UHI due to decrease on the air temperature. For instance, in a scenario with $100 \%$ greenery coverage, the vertical greenery systems successfully lowered the minimum estate air temperature by $1^{\circ} \mathrm{C}$.

Cheng (2010) conducted an experimental study aiming to investigate the impacts of using vegetated wall on the thermal performance of a public housing apartment located in Hong Kong. The results showed that, there was a decline on indoor air temperature as the vertical greenery made barrier against solar heat transfer. Moreover, energy consumption of air-conditioner decreased up to $30 \%$ when the bare concrete replaced to vertical greenery on the building envelope. 
In another study, eight different vertical greenery systems have been evaluated to explore their thermal effects on surface and ambient temperatures (Wong, et al., 2009). The results showed that two types of these Vertical greenery systems namely as VGSs 3 (living wall- Grid and modular, vertical interface, mixed substrate) and VGSs 4 (living wall - Modular panel, vertical interface, inorganic substrate) had the most positive impacts on the cooling systems. These types of walls decreased the wall and substrate layer temperatures by about $4-12^{\circ} \mathrm{C}$. Further analysis showed that the VGSs 4 and VGSs 1 can noticeably reduce the surface temperature of building façade during the days in the tropical climate.

\subsection{Studies on green pavement}

Green pavement is an effective strategy to reduce the effects of UHI in the urban area. However, few studies have been carried out in the selected cities to evaluate the performance of green pavement on mitigation of UHI. Wong et al. (2005) designed a mobile survey to investigate both the severity of UHI effect and cooling impacts of green areas at macro-level in Singapore. The proposed survey showed that the land uses and functions could influence outdoor air temperature and relative humidity directly. The results of study indicated that there was a great difference between the well planted area in suburb and central business district (CBD) area with little greenery area due to attendance of UHI. The maximum difference on air temperature was recorded for $4^{\circ} \mathrm{C}$.

During another study (Wong, et al., 2010) conducted through field measurement and two simulation programs in two city green areas, the impact of vegetated areas on energy consumption of nearby commercial buildings were investigated and the results demonstrated the beneficial and cooling impact of green space at vegetation space and surrounding areas. According to the results, the lowest temperature observed in the parks which were 25.2$27.5^{\circ} \mathrm{C}$ and $25.6-29.2^{\circ} \mathrm{C}$ in surrounding built environment. Green areas reduce the average of air temperature by up to $1.3^{\circ} \mathrm{C}$ as compared with those urban areas with no green pavement. In another study in Hong Kong, the cooling effects of green pedestrian canyons in two different conditions were examined through the field measurement. The findings showed that greenery in large extent impacts on the microclimate conditions positively. Furthermore, the study concluded that the pedestrian canyons with mature trees have better capability than young palms canyons to provide sufficiently comfort outdoor thermal conditions (Wong, et al., 2010). Table 3 summarized the researches on the impact of green pavement on UHI mitigation.

Table 3. Green pavement effect on UHI mitigation

\begin{tabular}{|c|c|c|c|c|}
\hline Author & Method & Parameter & Result & Location \\
\hline $\begin{array}{c}\text { (Wong, et al., } \\
\text { 2009) }\end{array}$ & mobile survey & Temperature & $\begin{array}{c}\text { The findings shows that with well planted area } \\
\text { many benefits could obtain such as ecological } \\
\text { advantage and social as well as thermal aspect. } \\
\text { Moreover, more concern need during replace green } \\
\text { area with buildings according to the green area } \\
\text { influence on outdoor air temperature and UHI } \\
\text { reduction capacity. }\end{array}$ & Singapore \\
\hline $\begin{array}{c}\text { (Wong \& Yu, } \\
\text { 2005) }\end{array}$ & $\begin{array}{l}\text { field } \\
\text { measurement } \\
\text { simulation }\end{array}$ & Temperature & $\begin{array}{l}\text { According to the findings there is a relation between } \\
\text { the amount of green space and the UHI mitigation. } \\
\text { Also Green areas reduce the average of air } \\
\text { temperature by up to } 1.3^{\circ} \mathrm{C} \text { as compared with those } \\
\text { urban areas with no green pavement }\end{array}$ & Singapore \\
\hline $\begin{array}{c}\text { (Wong, et al., } \\
\text { 2010) }\end{array}$ & $\begin{array}{c}\text { Field } \\
\text { measurement }\end{array}$ & Temperature & $\begin{array}{l}\text { Greenery in large extent impacts on the } \\
\text { microclimate conditions positively and the best } \\
\text { effect obtain from mature trees with dense foliage }\end{array}$ & $\begin{array}{l}\text { Hong } \\
\text { Kong }\end{array}$ \\
\hline
\end{tabular}

According to the previous studies in the selected cities, green pavements have been not investigated extensively in urban context of Malaysia. Further studies should be implemented to determine the role of these elements on decreasing the UHI effects as well as energy consumption in the building sectors (Jaafar, Said, \& Rasidi, 2012; Safikhani, et al., 2014). 
Figure 6 summarizes and presents the strategies that have been applied to mitigate the UHI in Hong Kong, Singapore and Kuala Lumpur. Also, it shows the effective solutions that have been established with regards to urban morphology, low albedo materials and green façade specified according to the context of cities.

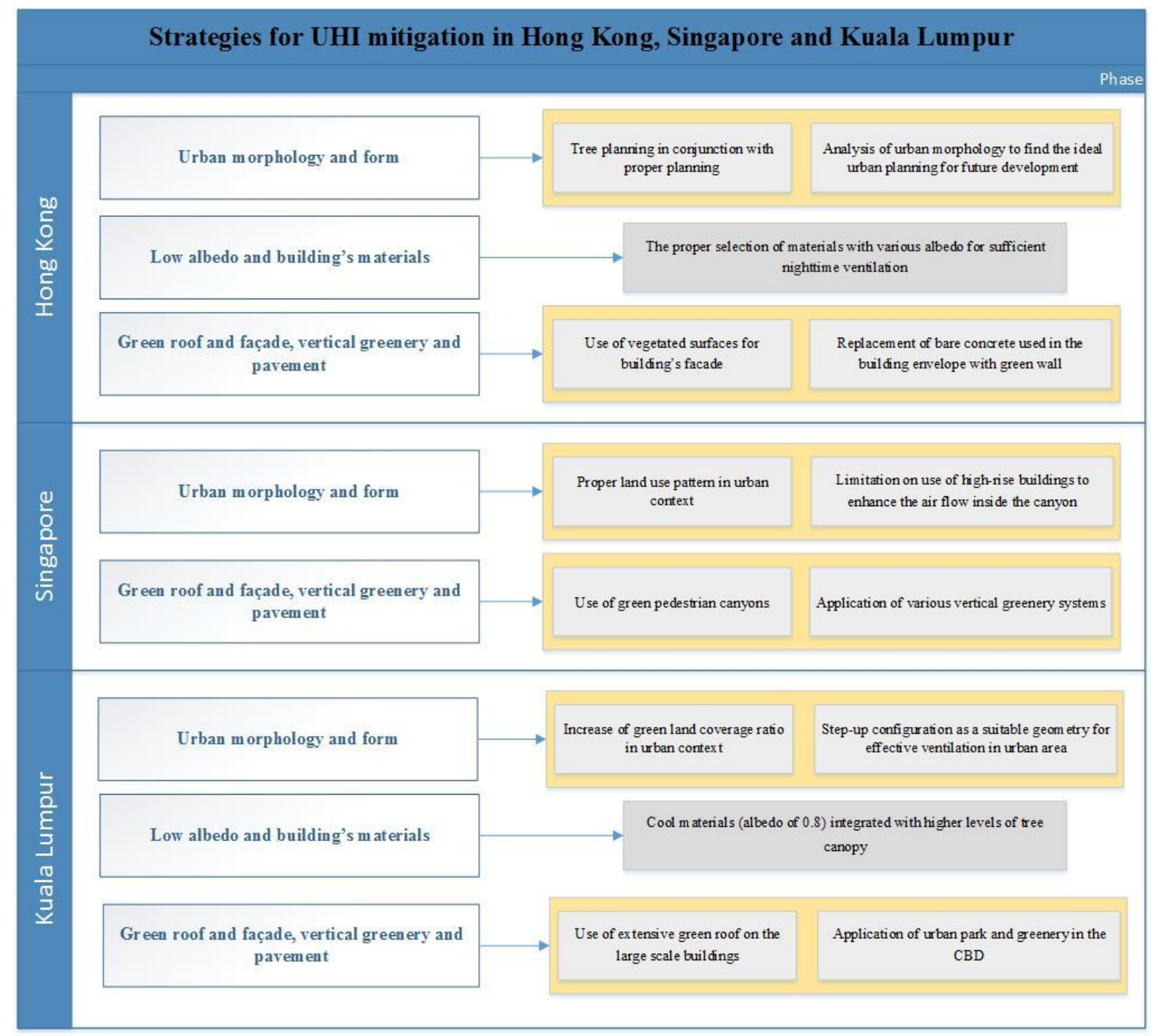

Figure 6. The UHI mitigation through the alternative strategies in the selected cities

\section{Discussions and Conclusions}

The current study introduces environmental temperature, energy consumption and OAQ as three imperative parameters to evaluate the UHI in the urban scale. Furthermore, review on methods and techniques for evaluation of UHI in the metropolitan cities showed that field measurement, CFD simulation and urban canopy models are most applicable methods that present reliable results. Moreover, as an advantage of the CFD, it is able to capture dynamics of air flow in urban canopies and present the UHI distribution through the urban area accurately. However, it should be noted that there is a need to do such simplification in the Navier-Stokes equations on application of CFD due to complicated atmospheric interactions of phenomena in the urban scale. Thus, meso-scale and micro-scale can be used in studies on the UHI to find out the valid and credible outcome.

The study further reviewed studies on the UHI mitigation in South-East Asian metropolitan cities and found that the urban morphology, building materials and application of different types of greenery on the building façade are some effective techniques which have been used to reduce the UHI. Review of studies on urban morphology and building forms showed that land cover change and pattern of urban land use are critical factors that influence 
on mitigation or intensification of the UHI. The study further found that the number of studies on urban morphology and its effect on the UHI in Singapore is higher than that of Hong Kong and Kuala Lumpur. Thus, further investigation is required especially in Kuala Lumpur to determine how the UHI effects can be mitigated through re-designing the existing urban morphology and future planning.

Building materials have been found as a crucial factor to reduce outdoor air temperature and energy consumption in the studied cities. The review ascertained that low albedo materials on the building façade can reduce the solar heat absorption and provide adequate comfort condition in urban areas. However, limited studies have been conducted previously in Singapore, Kuala Lumpur and Hong Kong to predict how changes on the building materials could govern the OAQ and energy consumption. Further studies are recommended to predict the effect of low albedo materials at large scale especially in city centres where excessive thermal stress endangers human thermal comfort.

In addition to urban morphology and building materials, the study found many studies on the application of greenery especially on the building façade in South-East Asian cities to reduce the difference of environmental temperature between urban and rural areas. Green roof as the most popular greenery technique is mostly applied in Singapore followed by Hong Kong and Kuala Lumpur. Reviewed studies confirmed that green roof as an effective strategy on reduction of environmental temperature and energy consumption can be implemented at small or large scale in the urban context. Whilst, there are different types of green roofs such as extensive and intensive, further studies should be carried out, especially in Hong Kong and Kuala Lumpur, to determine how various green roofs work in different urban contexts. Experiences in Singapore as a lead country on using green roof in the South-east Asia could be established for further studies in the cities or even towns. Vertical greenery and green pavement are the other important alternatives, which have been rarely used in the previous studies. While there are relatively few studies on the evaluation of green pavement in Singapore and Hong Kong, such studies in the context of Kuala Lumpur are extremely rare. As there is a lack of scholarly studies in this field, it is hitherto impractical to compare the performance of green pavement with other greenery techniques. Green pavement that is normally used in the urban parks could significantly influence the UHI mitigation. Thus, further researches on green pavement are recommended in Kuala Lumpur and even in Singapore and Hong Kong to demonstrate its relevancy on providing thermally comfortable outdoor environment. Furthermore, the previous studies in the studied cities predominantly focused on the environmental temperature as a decisive parameter to evaluate the performance of green pavement. Saving on energy consumption and OAQ introduced as the imperative parameters on evaluation of the UHI should be established in future studies to present novel outcomes on application of green pavement in the urban area.

Finally, from a critical point of view, the following aspects are required to be taken into account in future studies:

- The interrelations of urban morphology and UHI intensity result in very complex and multifaceted scenarios which require more in-depth and interdisciplinary studies towards mitigating the UHI effects in various urban settings under different climatic conditions.

- Future studies are recommended to be more focused on putting forward new solutions that are capable of being integrated with diverse urban contexts while being economically justifiable.

- Future studies are suggested to integrate multiple UHI mitigation strategies as a portfolio of solutions in order to optimize the effectiveness of combined strategies as well as their possible counter-interactions.

\section{Acknowledgements}

We would like to thank Prof. Dr. Edward $\mathrm{Ng}$ from Chinese University of Hong Kong and his research group for providing the street level photographs of Hong Kong and Singapore cities. The work of Dr. Amirhosein Ghaffarianhoseini in this study is supported by the sustainability science cluster at University of Malaya (UM) under grant \# GC002A-15SUS. The work of Dr. Zhihua Wang in this study is supported by U.S. National Science Foundation (NSF) under grant \# CBET-1435881. 


\section{References}

The government of the Hong Kong Special Administrative Region. (2016). The Hong Kong Observatory, Available on: http://www.hko.gov.hk/climate_changelobs_hk_temp_e.htm. Accessed: [08/06/2016].

Abahri, K., Belarbi, R., \& Trabelsi, A. . (2011). Contribution to analytical and numerical study of combined heat and moisture transfers in porous building materials. Building and Environment, 46(7), 1354-1360.

Adamowski, J., \& Prokoph, A. (2013 ). Assessing the impacts of the urban heat island effect on streamflow patterns in Ottawa, Canada. Journal of Hydrology, 496, 225-237.

Aguilar, E., Auer, I., Brunet, M., Peterson, T. C., \& Wieringa, J. . (2003 ). Guidance on metadata and homogenization. WMO $T D$ (1186-53).

Ahmed, A. Q., Ossen, D. R., Jamei, E., Manaf, N. A., Said, I., \& Ahmad, M. H. . (2015). Urban surface temperature behaviour and heat island effect in a tropical planned city. Theoretical and Applied Climatolog, 119, 493-514.

Akbari, H. (2005). Energy Saving Potentials and Air Quality Benefits of Urban Heat Island Mitigation. Lawrence Berkeley National Laboratory. Avaliable on: http://www.osti.gov/scitech/biblio/860475. Accessed: [28/12/2015].

Akbari, H., \& Matthews, H. D. (2012). Global cooling updates: Reflective roofs and pavements. Energy and Buildings, 55, 2 6.

Akbari, H., Cartalis, C., Kolokotsa, D., Muscio, A., Pisello, A. L., Rossi, F., ... \& Zinzi, M. . (2016). Local climate change and urban heat island mitigation techniques-the state of the art. Journal of Civil Engineering and Management, $22(1), 1-16$.

Akbari, H., Rose, L. S., \& Taha, H. (2003). Analyzing the land cover of an urban environment using high-resolution orthophotos. Landscape and urban planning, 63(1), 1-14.

Al-mulali, U., Sab, C. N. B. C., \& Fereidouni, H. G. (2012). Exploring the bi-directional long run relationship between urbanization, energy consumption, and carbon dioxide emission. Energy, 46(1), 156-167.

Alexandri, E., \& Jones, P. (2008). Temperature decreases in an urban canyon due to green walls and green roofs in diverse climates. Building and Environment, 43(4), 480-493.

Arifwidodo, S., \& Chandrasiri, O. (2015). Urban Heat Island and Household Energy Consumption in Bangkok, Thailand. Energy Procedia, 79, 189-194.

Arnfield, A. J. (2003). Two decades of urban climate research: a review of turbulence, exchanges of energy and water, and the urban heat island. International journal of climatology, 23(1), 1-26.

Becker, F., \& Li, Z.L. (1995). Surface temperature and emissivity at various scales: Definition, measurement and related problems. Remote Sensing Reviews, 12(3-4), 225-253.

Belle, I., Wang, T., \& Hassler, U. . (2015). Age of land as parameter for sustainable transformation of Singapore's building stock. Habitat International, 48, 20-29.

Boehme, P., Berger, M., \& Massier, T. (2015). Estimating the building based energy consumption as an anthropogenic contribution to Urban Heat Islands. Sustainable Cities and Society, 19, 373-384.

Bunnell, T., Barter, P. A., \& Morshidi, S. (2002). Kuala Lumpur metropolitan area: A globalizing city-region. Cities, 19(5), 357-370.

Buyadi, S. N. A., Mohd, W. M. N. W., \& Misni, A. (2015). Vegetation's Role on Modifying Microclimate of Urban Resident. Procedia - Social and Behavioral Sciences, 202, 400-407. doi: http://dx.doi.org/10.1016/j.sbspro.2015.08.244

Cermak, J. E. (1996). Thermal effects on flow and dispersion over urban areas: capabilities for prediction by physical modeling. Atmospheric Environment, 30(3), 393-401.

Chan, A. L. S. (2011). Developing a modified typical meteorological year weather file for Hong Kong taking into account the urban heat island effect. Building and Environment, 46(12), 2434-2441.

Change. (2007). Intergovernmental Panel On Climate. Climate change 2007: The physical science basis. Agenda, 6(07), 333.

Chen, H., Ooka, R., Huang, H., \& Tsuchiya, T. (2009). Study on mitigation measures for outdoor thermal environment on present urban blocks in Tokyo using coupled simulation. Building and Environment, 44(11), 2290-2299.

Cheng, C. Y., Cheung, K. K., \& Chu, L. M. . (2010). Thermal performance of a vegetated cladding system on facade walls. Building and environment, 45(8), 1779-1787.

Chow, W. T., Akbar, S. N. A. B. A., Heng, S. L., \& Roth, M. (2016). Assessment of measured and perceived microclimates within a tropical urban forest. Urban Forestry \& Urban Greening, 16, 62-75.

Chow, W. T. L., Roth, M. (2006). Temporal dynamics of the urban heat island of Singapore. International journal of climatology, 26, 2243-2260.

Cohen, A. J., Anderson, H. R., Ostro, B., Pandey, K. D., Krzyzanowski, M., Künzli, N., et al. . (2004). Urban air pollution. Comparative Quantification of Health Risks, 2, 1353-1433.

Corlett, R. T. (2011). Terrestrial ecosystems. In P. K. L. Ng, R. T. Corlett, \& H. T. W. Tan (Eds.), Singapore biodiversity An encyclopedia of the natural environment and sustainable development. Singapore: Editions Didier Millet., 552.

Costa, S., Ferreira, J., Silveira, C., Costa, C., Lopes, D., Relvas, H., ... \& Paulo Teixeira, J. . (2014). Integrating health on air quality assessment-Review report on health risks of two major European outdoor air pollutants: PM and NO2. Journal of Toxicology and Environmental Health, Part B, 17(6), 307-340.

de La Flor, F. S., \& Dominguez, S. A. (2004). Modelling microclimate in urban environments and assessing its influence on the performance of surrounding buildings. Energy and Buildings, 36(5), 403-413.

Deng, Y., Chan, E. H., \& Poon, S. W. . (2016). Challenge-driven design for public housing: The case of Hong Kong. Frontiers of Architectural Research, 5, 213-224.

Dhalluin, A., \& Bozonnet, E. (2015). Urban heat islands and sensitive building design-A study in some French cities' context. Sustainable Cities and Society, 19, 292-299. 
Elsayed, I. S. (2012). Mitigation of the urban heat island of the city of Kuala Lumpur, Malaysia. Middle-East Journal of Scientific Research, 11(11), 1602-1613.

EPP. (2016). Greening Kreater Luala Available http://etp.pemandu.gov.my/Greater_Kuala_Lumpur_Klang_Valley-@-Greater_Kuala_Lumpur_-_EPP_6; Greening Greater Kuala Lumpur to Ensure Residents Enjoy Sufficient Green Space.aspx. Accessed: [12.06.2016].

Fernández, F. J., Alvarez-Vázquez, L. J., García-Chan, N., Martínez, A., \& Vázquez-Méndez, M. E. (2015). Optimal location of green zones in metropolitan areas to control the urban heat island. Journal of Computational and Applied Mathematics, 289, 412-425.

Gago, E. J., Roldán, J., Pacheco-Torres, R., \& Ordoñez, J. . (2013). The city and urban heat islands: A review of strategies to mitigate adverse effects. Renewable and Sustainable Energy Reviews, 25, 749-758.

Georgescu, M., Chow, W. T. L., Wang, Z. H., Brazel, A., Trapido-Lurie, B., Roth, M., \& Benson-Lira, V. . (2015). Prioritizing urban sustainability solutions: coordinated approaches must incorporate scale-dependent built environment induced effects. Environmental Research Letters, 10(6), 061001.

Giridharan, R., Lau, S.S.Y,. Ganesan, S., Givoni, B. (2008). Lowering the outdoor temperature in high-rise high-density residential developments of coastal Hong Kong: The vegetation influence. Building and Environment, 43(10), 1583-1595. doi: http://dx.doi.org/10.1016/j.buildenv.2007.10.003

Giridharan, R., Lau, SSY., Ganesan, S. (2005). Nocturnal heat island effect in urban residential developments of Hong Kong. Energy and Buildings, 37(9), 964-971.

Gluch, R., . Quattrochi, D.A,. Luvall, J.C. (2006). A multi-scale approach to urban thermal analysis. Remote Sensing of Environment, 104(2), 123-132.

Godish, T., Davis, W. T., \& Fu, J. S. . (2014). Air quality. CRC Press.

Goldreich, Y. (2006). Ground and top of canopy layer urban heat island partitioning on an airborne image. Remote Sensing of Environment, 104(2), 247-255.

Harlan, S. L., \& Ruddell, D.M. . (2011). Climate change and health in cities: Impacts of heat and air pollution and potential co-benefits from mitigation and adaptation. Current Opinion in Environmental Sustainability, 3(3), 126- 134.

Huang, L., . Li, J., Zhao, D., Zhu, J. (2008). A fieldwork study on the diurnal changes of urban microclimate in four types of ground cover and urban heat island of Nanjing, China. Building and environment, 43(1), 7-17.

Imhoff, M. L., Zhang, P., Wolfe, R. E., \& Bounoua, L. (2010). Remote sensing of the urban heat island effect across biomes in the continental USA. Remote Sensing of Environment, 114(3), 504-513.

Ismail, A., Samad, M. H. A., \& Rahman, A. M. A. . (2011). The investigation of green roof and white roof cooling potential on single storey residential building in the Malaysian climate. World Academy of Science, Engineering and Technology, 52, 129-137.

Jaafar, B., Said, I., \& Rasidi, M. H. . (2012). Evaluating the impact of vertical greenery system on cooling effect on high rise buildings and surroundings: a review. Jurnal Ruas, 9(2), 1.

Jim, C. Y. (2015). Assessing climate-adaptation effect of extensive tropical green roofs in cities. Landscape and Urban Planning, 138, 54-70.

Jim, C. Y., \& Peng, L. L. . (2012). Weather effect on thermal and energy performance of an extensive tropical green roof. Urban Forestry \& Urban Greening, 11(1), 73-85.

Jusuf, S. K., Wong, N. H., Hagen, E., Anggoro, R., \& Hong, Y. . (2007). The influence of land use on the urban heat island in Singapore. Habitat International, 31(2), 232-242.

Kaloustian, N., \& Diab, Y. . (2015). Effects of urbanization on the urban heat island in Beirut. Urban Climate, 14, 154-165.

Kato, S., \& Yamaguchi, Y. (2005). Analysis of urban heat-island effect using ASTER and ETM+ Data: Separation of anthropogenic heat discharge and natural heat radiation from sensible heat flux. Remote Sensing of Environment, 99(1), 44-54.

Kleerekoper, L., van Esch, M., \& Salcedo, T. B. . (2012). How to make a city climate-proof, addressing the urban heat island effect. Resources, Conservation and Recycling, 64, 30-38.

Kolokotroni, M., Giannitsaris, I., \& Watkins, R. (2006). The effect of the London urban heat island on building summer cooling demand and night ventilation strategies. Solar Energy, 80(4), 383-392.

Kolokotroni, M., Ren, X., Davies, M., \& Mavrogianni, A. . (2012). London's urban heat island: Impact on current and future energy consumption in office buildings. Energy and buildings, 47, 302-311.

Kuznik, F., David, D., Johannes, K., \& Roux, J. J. . (2011). A review on phase change materials integrated in building walls. Renewable and Sustainable Energy Reviews, 15(1), 379-391.

Lam, K.-C., Ng, S.-L., Hui, W.-C., \& Chan, P.-K. (2005). Environmental quality of urban parks and open spaces in Hong Kong. Environmental Monitoring and Assessment, 111(1-3), 55-73.

Landsberg, H. E. (1981). The urban climate Academic press, 28.

Li, X. X., \& Norford, L. K. . (2016). Evaluation of cool roof and vegetations in mitigating urban heat island in a tropical city, Singapore. Urban Climate, 16, 59-74.

Ma, T., Østergaard, P. A., Lund, H., Yang, H., \& Lu, L. . (2014). An energy system model for Hong Kong in 2020. Energy, 68, 301-310.

Martin, P., Baudouin, Y., \& Gachon, P. (2014). An alternative method to characterize the surface urban heat island. International journal of biometeorology, 59(7), 849-861.

Matthews, T., Lo, A. Y., \& Byrne, J. A. . (2015). Reconceptualizing green infrastructure for climate change adaptation: Barriers to adoption and drivers for uptake by spatial planners. Landscape and Urban Planning, 138, 155-163.

Mavrogianni, A., Davies, M., Batty, M., Belcher, S., Bohnenstengel, S., Carruthers, D., et al. . (2011). The comfort, energy and health implications of London's urban heat island. Building Services Engineering Researchand Technology. Available on: http://dx.doi.org/10.1177/0143624410394530. Accessed: 28/12/2015. 
Mekhilef, S., Safari, A., Mustaffa, W. E. S., Saidur, R., Omar, R., \& Younis, M. A. A. . (2012). Solar energy in Malaysia: current state and prospects. Renewable and Sustainable Energy Reviews, 16(1), 386-396.

Mirzaei, P. A. (2015). Recent challenges in modeling of urban heat island. Sustainable Cities and Society, 19, $200-206$.

Mirzaei, P. A., \& Haghighat, F. . (2010). Approaches to study urban heat island-abilities and limitations. Building and Environment, 45(10), 2192-2201. doi: http://dx.doi.org/10.1016/j.buildenv.2010.04.001

Morris, K. I., Chan, A., Salleh, S. A., Ooi, M. C. G., Oozeer, M. Y., \& Abakr, Y. A. . (2016). Numerical study on the urbanisation of Putrajaya and its interaction with the local climate, over a decade. Urban Climate, 16, 1-24.

Morris, K. I., Salleh, S. A., Chan, A., Ooi, M. C. G., Abakr, Y. A., Oozeer, M. Y., \& Duda, M. . (2015). Computational study of urban heat island of Putrajaya, Malaysia. Sustainable Cities and Society, 19, 359-372.

Nichol, J. E., Fung, W.Y., Lam, K.S., Wong, M.S. . (2009). Urban heat island diagnosis using ASTER satellite images and 'in situ' air temperature. . Atmospheric Research, 94(2), 276-284.

O’Malley, C., Piroozfar, P., Farr, E. R., \& Pomponi, F. (2015). Urban Heat Island (UHI) mitigating strategies: A case-based comparative analysis. Sustainable Cities and Society, 19, 222-235.

Oberndorfer, E., Lundholm, J., Bass, B., Coffman, R. R., Doshi, H., Dunnett, N., ... \& Rowe, B. (2007). Green roofs as urban ecosystems: ecological structures, functions, and services. BioScience, 57(10), 823-833.

Oke, T. R. (2004). Initial guidance to obtain representative meteorological observations at urban sites. Geneva: World Meteorological Organization, 81.

Pan, W., Qin, H., \& Zhao, Y. . (2016). Challenges for energy and carbon modeling of high-rise buildings: The case of public housing in Hong Kong. Resources, Conservation and Recycling., In Press.

Paulina, W., Poh-Chin, L., \& Melissa, H. . (2015). Temporal Statistical Analysis of Urban Heat Islands at the Microclimate Level. Procedia Environmental Sciences, 26, 91-94.

Peng, L. L., \& Jim, C. Y. . (2015). Economic evaluation of green-roof environmental benefits in the context of climate change: The case of Hong Kong. Urban Forestry \& Urban Greening, 14(3), 554-561.

Pisello, A. L., Castaldo, V. L., Pignatta, G., Cotana, F., \& Santamouris, M. (2016). Experimental in-lab and in-field analysis of waterproof membranes for cool roof application and urban heat island mitigation. Energy and Buildings, 114, $180-190$.

Poon, W. C., Herath, G., Sarker, A., Masuda, T., \& Kada, R. . (2016). River and fish pollution in Malaysia: A green ergonomics perspective. Applied ergonomics, In Press(doi:10.1016/j.apergo.2016.02.009).

PopulationStructure. (2016). Population and Population Structure. Available on: http://www.singstat.gov.sg/statistics/browseby-theme/population-and-population-structure. Accessed: [07/06/2016]. Statistics Singapore.

Priyadarsini, R. (2009). Urban Heat Island and its impact on building energy consumption. Advances in building energy research, 3(1), 261-270.

Priyadarsini, R., \& Wong, N. H. . (2007). An Investigation of the Urban Heat Island of Singapore. 41st Annual Conference of the Architectural Science Association ANZAScA at Deakin University.

Priyadarsini, R., Hien, W. N., \& David, C. K. W. . (2008). Microclimatic modeling of the urban thermal environment of Singapore to mitigate urban heat island. Solar energy, 82(8), 727-745.

Qin, Y. (2015). A review on the development of cool pavements to mitigate urban heat island effect. Renewable and Sustainable Energy Reviews, 52, 445-459.

Radhi, H., Sharples, S., \& Assem, E. (2015). Impact of urban heat islands on the thermal comfort and cooling energy demand of artificial islands-A case study of AMWAJ Islands in Bahrain. Sustainable Cities and Society, 19, 310-318.

Rajagopalan, P., Lim, K. C., \& Jamei, E. . (2014). Urban heat island and wind flow characteristics of a tropical city. Solar Energy, 107, 159-170.

Ren, L., Wang, W., Wang, J., \& Liu, R. . (2015). Analysis of energy consumption and carbon emission during the urbanization of Shandong Province, China. Journal of Cleaner Production, 103, 534-541.

Roth, M., \& Chow, W. T. . (2012). A historical review and assessment of urban heat island research in Singapore. Singapore Journal of Tropical Geography, 33(3), 381-397.

Rydin, Y., Bleahu, A., Davies, M., Dávila, J. D., Friel, S., De Grandis, G... \& Lai, K. M. (2012). Shaping cities for health: complexity and the planning of urban environments in the 21st century. The Lancet, 379(9831), 2079-2108.

Safikhani, T., Abdullah, A. M., Ossen, D. R., \& Baharvand, M. . (2014). A review of energy characteristic of vertical greenery systems. Renewable and Sustainable Energy Reviews, 40, 450-462.

Sahrir, S., Bachok, S., \& Osman, M. M. . (2014). Environmental and Health Impacts of Airport Infrastructure Upgrading: Kuala Lumpur International Airport 2. Procedia-Social and Behavioral Sciences, 153, 520-530.

Sailor, D. J. (2008). A green roof model for building energy simulation programs. Energy and buildings, 40(8), 1466-1478.

Sailor, D. J., \& Dietsch, N. . (2007). The urban heat island mitigation impact screening tool (MIST). Environmental Modelling \& Software, 22(10), 1529-1541.

Salamanca, F., Georgescu, M., Mahalov, A., Moustaoui, M., Wang, M., \& Svoma, B. M. . (2013). Assessing summertime urban air conditioning consumption in a semiarid? environment. Environmental Research Letters, 8(3), 034022.

Salmond, J. A., Roth, M., Oke, T. R., Christen, A., \& Voogt, J. A. . (2012). Can surface-cover tiles be summed to give neighborhood fluxes in cities? Journal of Applied Meteorology and Climatology, 51(1), 133-149.

Santamouris, M. (2007). Heat island research in Europe: the state of the art. Advances in building energy research, 1(1), 123150.

Santamouris, M. (2013). Using cool pavements as a mitigation strategy to fight urban heat island-A review of the actual developments. Renewable \& Sustainable Energy Reviews, 26, 224-240.

Santamouris, M., Papanikolaou, N., Livada, I., Koronakis, I., Georgakis, C., Argiriou, A., \& Assimakopoulos, D. N. . (2001). On the impact of urban climate on the energy consumption of buildings. Solar energy, 70(3), 201-216.

Santamouris, M., Synnefa, A., \& Karlessi, T. (2011). Using advanced cool materials in the urban built environment to mitigate heat islands and improve thermal comfort conditions. Solar Energy, 85(12), 3085-3102. 
Schrijvers, P. J. C., Jonker, H. J. J., Kenjereš, S., \& de Roode, S. R. (2015). Breakdown of the night time urban heat island energy budget. Building and Environment, 83, 50-64.

Seik, F. T. (2001). Planning and design of Tampines, an award-winning high-rise, high-density township in Singapore. Cities, $18(1), 33-42$.

Shahidan, M. F., Jones, P. J., Gwilliam, J., \& Salleh, E. (2012). An evaluation of outdoor and building environment cooling achieved through combination modification of trees with ground materials. Building and Environment, 58, 245257. doi: http://dx.doi.org/10.1016/j.buildenv.2012.07.012

Shi, Y., Ren, C., Zheng, Y., \& Ng, E. . (2015). Mapping the urban microclimatic spatial distribution in a sub-tropical highdensity urban environment. Architectural Science Review, 1-15. DOI: 10.1080/00038628.00032015.01105195.

Siu, L. W., \& Hart, M. A. (2013). Quantifying urban heat island intensity in Hong Kong SAR, China. Environmental monitoring and assessment, 185(5), 4383-4398.

Smith, C., \& Levermore, G. (2008). Designing urban spaces and buildings to improve sustainability and quality of life in a warmer world. Energy policy, 36(12), 4558-4562.

Srivastava, N., Prashar, S., Surjan, A., \& Shaw, R. (2012). Redefining Urban ecosystems. Ecosystem-Based Adaptation, 12, $145-173$

Stewart, I. D. (2011). A systematic review and scientific critique of methodology in modern urban heat island literature. International journal of climatology, 31(2), 200-217.

Streutker, D. R. (2002). A remote sensing study of the urban heat island of Houston, Texas. International Journal of Remote Sensing, 23(13), 2595-2608.

StructurePlan. (2016). Kuala Lumpur Structure Plan. Urban design and landscape. Available on: http://www.dbkl.gov.my/pskl2020/english/urban_design_and_landscape/. Visited: [12.06.2016].

Taha, H. (1997). Modeling the impacts of large-scale albedo changes on ozone air quality in the South Coast Air Basin. Atmospheric Environment, 31(11), 1667-1676.

Takebayashi, H., \& Moriyama, M. (2007). Surface heat budget on green roof and high reflection roof for mitigation of urban heat island. Building and Environment, 42(8), 2971-2979.

Taleb, D., \& Abu-Hijleh, B. (2013). Urban heat islands: potential effect of organic and structured urban configurations on temperature variations in Dubai, UAE. Renewable Energy, 50, 747-762.

Tan, C. L., Wong, N. H., Tan, P. Y., Jusuf, S. K., \& Chiam, Z. Q. (2015). Impact of plant evapotranspiration rate and shrub albedo on temperature reduction in the tropical outdoor environment. Building and Environment, 94, 206-217. doi: http://dx.doi.org/10.1016/j.buildenv.2015.08.001

Tan, M., \& Li, X. (2015). Quantifying the effects of settlement size on urban heat islands in fairly uniform geographic areas. Habitat International, 49, 100-106.

Tan, P. Y., \& bin Abdul Hamid, A. R. . (2014). Urban ecological research in Singapore and its relevance to the advancement of urban ecology and sustainability. Landscape and Urban Planning, 125, 271-289.

Tan, Z., Lau, K. K. L., \& Ng, E. . (2016). Urban tree design approaches for mitigating daytime urban heat island effects in a high-density urban environment. Energy and Buildings, 114, 265-274.

Taslim, S., Parapari, D. M., \& Shafaghat, A. (2015). Urban Design Guidelines to Mitigate Urban Heat Island (UHI) Effects In Hot-Dry Cities. Jurnal Teknologi, 74(4).

Teriman, S., Yigitcanlar, T., \& Mayere, S. (2009). Urban sustainability and growth management in South-East Asian cityregions: the case of Kuala Lumpur and Hong Kong. Plan Malays, 7(1), 47-68.

Theophilou, M. K., \& Serghides, D. (2015). Estimating the characteristics of the Urban Heat Island Effect in Nicosia, Cyprus, using multiyear urban and rural climatic data and analysis. Energy and Buildings, 108, 137-144.

Tsang, S. W., \& Jim, C. Y. (2011). Theoretical evaluation of thermal and energy performance of tropical green roofs. Energy, 36(5), 3590-3598.

Tsilini, V., Papantoniou, S., Kolokotsa, D. D., \& Maria, E. A. (2015). Urban gardens as a solution to energy poverty and urban heat island. Sustainable Cities and Society, 14, 323-333.

Tso, C. P. (1996). A survey of urban heat island studies in two tropical cities. Atmospheric Environment, 30(3), 507-519.

Tzoulas, K., K. Korpela, S. Venn, V. Yli-Pelkonen, A. Kazmierczak, J. Niemela, et al. . (2007). Promoting ecosystem and human health in urban areas using Green Infrastructure: A literature review. Landscape and Urban Planning, 81(3), 167-178.

Uehara, K., Murakami, S., Oikawa, S., \& Wakamatsu, S. (2000). Wind tunnel experiments on how thermal stratification affects flow in and above urban street canyons. Atmospheric Environment, 34(10), 1553-1562.

UNDESA/PD. (2014). United Nations Department of Economic and Social Affairs, World urbanisation prospects: The 2014 revision. New York: United Nations.

Walcek, C. J., \& Yuan, H. H. (1995). Calculated influence of temperature-related factors on ozone formation rates in the lower troposphere. Journal of applied meteorology, 34(5), 1056-1069.

Wang, H., Shen, Q., Tang, B.S., Skitmore, M. . (2013). An integrated approach to supporting land-use decisions in site redevelopment for urban renewal in Hong Kong. Habitat International, 38, 70-80.

Wang, H., Zhang, X., \& Skitmore, M. . (2015). Implications for sustainable land use in high-density cities: Evidence from Hong Kong. Habitat International, 50, 23-34.

Wang, X. R., Hui, E. C. M., Choguill, C., \& Jia, S. H. . (2015). The new urbanization policy in China: Which way forward? Habitat International, 47, 279-284.

Wang, Y., Berardi, U., \& Akbari, H. (2016). Comparing the effects of urban heat island mitigation strategies for Toronto, Canada. Energy and Buildings, 114, 2-19.

Wang, Y., Chen, L., \& Kubota, J. . (2016). The relationship between urbanization, energy use and carbon emissions: evidence from a panel of Association of Southeast Asian Nations (ASEAN) countries. Journal of Cleaner Production, 112, 1368-1374. 
Wang, Z. H., Bou - Zeid, E., \& Smith, J. A. . (2013). A coupled energy transport and hydrological model for urban canopies evaluated using a wireless sensor network. Quarterly Journal of the Royal Meteorological Society, 139(675), 16431657.

Wang, Z. H., Zhao, X., Yang, J., \& Song, J. . (2016). Cooling and energy saving potentials of shade trees and urban lawns in a desert city. Applied Energy, 161, 437-444.

Wanphen, S., \& Nagano, K. . (2009). Experimental study of the performance of porous materials to moderate the roof surface temperature by its evaporative cooling effect. Building and Environment, 44(2), 338-351.

Webb, R. (1998). Urban forestry in Kuala Lumpur, Malaysia. Arboricultural Journal, 22(3), 287-296.

WHO. (2014). World Health Organization. Ambient (outdoor) air quality and health. Fact Sheet No. 313. Updated in March.

Wong, J. K. W., \& Lau, L. S. K. . (2013). From the 'urban heat island'to the 'green island'? A preliminary investigation into the potential of retrofitting green roofs in Mongkok district of Hong Kong. Habitat International, 39, 25-35.

Wong, M. S., Peng, F., Zou, B., Shi, W. Z., \& Wilson, G. J. . (2016). Spatially Analyzing the Inequity of the Hong Kong Urban Heat Island by Socio-Demographic Characteristics. International Journal of Environmental Research and Public Health, 13(3), 317.

Wong, N. H., \& Yu, C. (2005). Study of green areas and urban heat island in a tropical city. Habitat International, 29(3), 547-558.

Wong, N. H., Chen, Y., Ong, C. L., \& Sia, A. . (2003). Investigation of thermal benefits of rooftop garden in the tropical environment. Building and environment, 38(2), 261-270.

Wong, N. H., Cheong, D. K. W., Yan, H., Soh, J., Ong, C., \& Sia, A. (2003). The effects of rooftop garden on energy consumption of a commercial building in Singapore. Energy and Buildings, 35(4), 353-364.

Wong, N. H., Jusuf, S. K., La Win, A. A., Thu, H. K., Negara, T. S., \& Xuchao, W. (2007). Environmental study of the impact of greenery in an institutional campus in the tropics. Building and environment, 42(8), 2949-2970.

Wong, N. H., S. K. Jusuf, N. I. Syafii, Y. X. Chen, N. Hajadi, H. Sathyanarayanan, et al. . (2011). Evaluation of the impact of the surrounding urban morphology on building energy consumption. Solar Energy, 85(1), 57-71.

Wong, N. H., Tan, A. Y. K., Chen, Y., Sekar, K., Tan, P. Y., Chan, D., ... \& Wong, N. C. (2010). Thermal evaluation of vertical greenery systems for building walls. Building and environment, 45(3), 663-672.

Wong, N. H., Tan, A. Y. K., Tan, P. Y., \& Wong, N. C. (2009). Energy simulation of vertical greenery systems. Energy and buildings, 41(12), 1401-1408.

Wong, P. P. Y., Lai, P. C., Low, C. T., Chen, S., \& Hart, M. ((2016)). The impact of environmental and human factors on urban heat and microclimate variability. Building and Environment, 95, 199-208.

Wu, J., Jenerette, G. D., Buyantuyev, A., \& Redman, C. L. . (2011). Quantifying spatiotemporal patterns of urbanization: The case of the two fastest growing metropolitan regions in the United States. Ecological Complexity, 8, 1-8.

Yang, J., Wang, Z. H., \& Kaloush, K. E. . (2015). Environmental impacts of reflective materials: Is high albedo a 'silver bullet'for mitigating urban heat island? Renewable and Sustainable Energy Reviews, 47, 830-843.

Yusuf, Y. A., Pradhan, B., \& Idrees, M. O. . (2014). Spatio-temporal Assessment of Urban Heat Island Effects in Kuala Lumpur Metropolitan City Using Landsat Images. Journal of the Indian Society of Remote Sensing, 42(4), 829-837.

Zhang, H., \& Jim, C. Y. . (2014). Contributions of landscape trees in public housing estates to urban biodiversity in Hong Kong. Urban Forestry \& Urban Greening, 13(2), 272-284.

Zhang, X. Q. (2016). The trends, promises and challenges of urbanisation in the world. Habitat International, 54(3), 241252.

Zhao, S., Zhou, D., \& Liu, S. (2016). Data concurrency is required for estimating urban heat island intensity. Environmental Pollution, 208, 118-124. 